See discussions, stats, and author profiles for this publication at: https://www.researchgate.net/publication/321785266

\title{
Sedimentary evidence of historical and prehistorical earthquakes along the Venta de Bravo Fault System, Acambay Graben (Central Mexico)
}

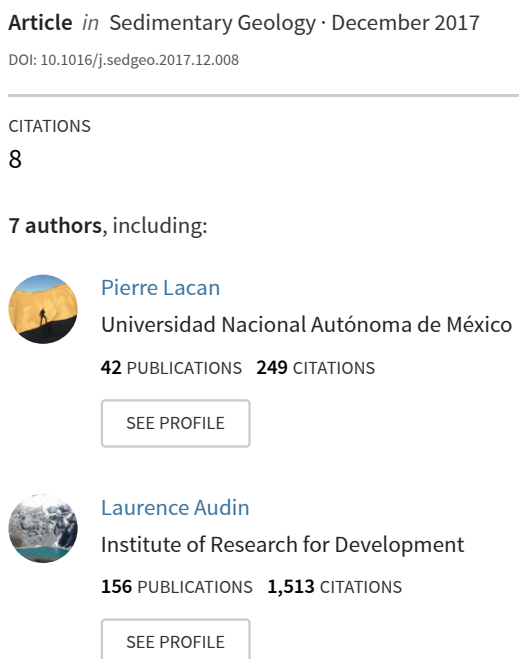

READS

226

María Ortuño

University of Barcelona

74 PUBLICATIONS 553 CITATIONS

SEE PROFILE

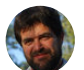

Hector Perea

Institut de Ciències del Mar - CSIC

77 PUBLICATIONS 475 CITATIONS

SEE PROFILE

Some of the authors of this publication are also working on these related projects:

Project Numerical Simulation of Earthquake Rupture using the Fiber Bundle Model View project

Project Surface Rupture Database (SURE) View project 


\section{Accepted Manuscript}

Sedimentary evidence of historical and prehistorical earthquakes along the Venta de Bravo Fault System, Acambay Graben (Central Mexico)

Pierre Lacan, María Ortuño, Laurence Audin, Hector Perea, Stephane Baize, Gerardo Aguirre-Díaz, F. Ramón Zúñiga

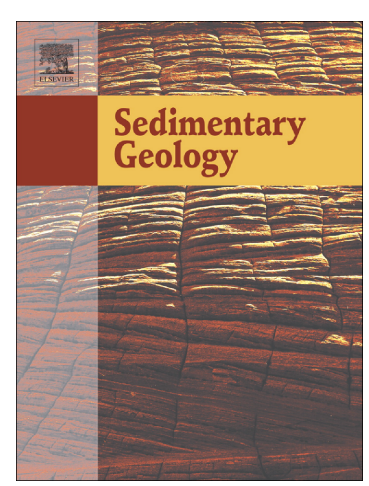

PII: S0037-0738(17)30275-0

DOI: https://doi.org/10.1016/j.sedgeo.2017.12.008

Reference: SEDGEO 5280

To appear in:

Received date: $\quad 30$ June 2017

Revised date: $\quad 7$ December 2017

Accepted date: $\quad 8$ December 2017

Please cite this article as: Pierre Lacan, María Ortuño, Laurence Audin, Hector Perea, Stephane Baize, Gerardo Aguirre-Díaz, F. Ramón Zúñiga , Sedimentary evidence of historical and prehistorical earthquakes along the Venta de Bravo Fault System, Acambay Graben (Central Mexico). The address for the corresponding author was captured as affiliation for all authors. Please check if appropriate. Sedgeo(2017), https://doi.org/ 10.1016/j.sedgeo.2017.12.008

This is a PDF file of an unedited manuscript that has been accepted for publication. As a service to our customers we are providing this early version of the manuscript. The manuscript will undergo copyediting, typesetting, and review of the resulting proof before it is published in its final form. Please note that during the production process errors may be discovered which could affect the content, and all legal disclaimers that apply to the journal pertain. 


\section{Sedimentary evidence of historical and prehistorical earthquakes along the Venta de Bravo Fault System, Acambay Graben (Central Mexico)}

Pierre Lacan ${ }^{\mathrm{a},{ }^{*},}$, María Ortuño ${ }^{\mathrm{b}}$, Laurence Audin ${ }^{\mathrm{c}}$, Hector Perea ${ }^{\mathrm{d}, \mathrm{e}}$, Stephane Baize ${ }^{\mathrm{f}}$, Gerardo Aguirre-Díaz $^{\text {a }}$, F. Ramón Zúñiga ${ }^{\text {a }}$

${ }^{a}$ Centro de Geociencias, Universidad Nacional Autónoma de México, Blvd. Juriquilla, 3001, 76230, Juriquilla, Querétaro, Mexico

${ }^{\mathrm{b}}$ RISKNAT group, Geomodels institute, Earth and Ocean Dynamics Department, Universitat de Barcelona, C/ Martí i Franquès s/n, 08028, Barcelona, Spain.

${ }^{\mathrm{c}}$ Institut des Sciences de la Terre, ISTerre, IRD, Université Joseph Fourier, Grenoble I, OSUG, France.

${ }^{\mathrm{d}}$ Barcelona-CSI, Institut de Ciències del Mar - CSIC, CMIMA, Psg. Martim de la Barceloneta, 3749, 08003, Barcelona, Spain.

${ }^{\mathrm{e}}$ GRD, Scripps Institution of Oceanography - University of California San Diego, La Jolla 92093, USA.

${ }^{\mathrm{f}}$ Institut de Radioprotection et Sûreté Nucléaire (IRSN), BP 17, 92262 Fontenay-aux-Roses, France.

Abstract: The Venta de Bravo normal fault is one of the longest structures in the intra-arc fault system of the Trans-Mexican Volcanic Belt. It defines, together with the Pastores Fault, the $80 \mathrm{~km}$ long southern margin of the Acambay Graben. We focus on the westernmost segment of the Venta de Bravo fault and provide new paleoseismological information, evaluate its earthquake history, and assess the related seismic hazard. We analyzed five trenches, distributed at three different sites, in

\footnotetext{
* Corresponding Autor. E-mail address: placan@geociencias.unam.mx (P. Lacan).
} 
which Holocene surface faulting offsets interbedded volcanoclastic, fluvio-lacustrine and colluvial deposits. Despite the lack of known historical destructive earthquakes along this fault, we found evidence of at least eight earthquakes during the late Quaternary. Our results indicate that this is one of the major seismic sources of the Acambay Graben, capable of producing by itself earthquakes with magnitudes $\left(\mathrm{M}_{\mathrm{W}}\right)$ up to 6.9 , with a slip rate of $0.22-0.24 \mathrm{~mm} \mathrm{yr}^{-1}$ and a recurrence interval between 1940 and 2390 years. In addition, a possible multi-fault rupture of the Venta de Bravo fault together with other faults of the Acambay Graben could result in a $M_{W}>7$ earthquake. These new slip rates, earthquake recurrence rates, and estimation of slips per event help advance our understanding of the seismic hazard posed by the Venta de Bravo fault and provide new parameters for further hazard assessment.

Key words: Active faults, Sedimentary recording, Paleoearthquakes, Seismic hazard, Acambay Graben, Central Mexico 


\section{Introduction}

Crustal active faults located in mid-continent plate interiors have significantly lower slip rates

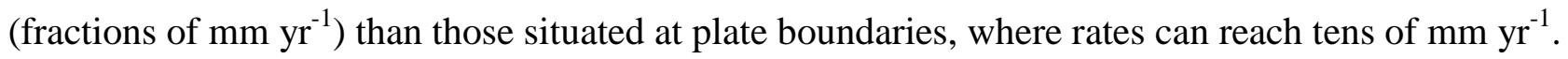
However, those slow faults can produce moderate to large earthquakes that may cause major damage and casualties (e.g., Urbina and Camacho, 1913; Meghraoui et al., 2001; Perea, 2009). Given the expected low slip rates, the instrumental and historical earthquake records are insufficient to estimate the recurrence intervals of the large and damaging seismic events, which are typically thousands of years (e.g., Lacan et al., 2012; Perea et al., 2012; Nivière et al., 2016). Thus, it is necessary to investigate the evidence left by fault activity in the geological and geomorphological records (e.g., Messager et al., 2010; Audemard and Michetti, 2011; Benavente et al., 2017). Typically, paleoseismological investigations across a fault imply digging a trench to expose the faulted geological record in order to analyze and correlate the different stratigraphic units, based on their rock or sediment type, their geometry and relative arrangement. The main objectives are to determine the timing of large earthquakes which ruptured along a specific fault, to estimate their magnitude(s) by measuring the amount of slip per event, and to evaluate the slip-rate of the seismotectonic structure.

Here, we describe, analyze, and interpret the sedimentary record along a specific fault system: the Venta de Bravo Fault. It is located within the Trans-Mexican Volcanic Belt tectonic region, a midcontinent plate interior volcanic arc characterized by the presence of low slip-rate active crustal faults that have produced large and destructive historical or early instrumental seismic events such as the 1567 Ameca (M 7.2; Suter, 2015), 1875 San Cristóbal de la Barranca (M $\mathrm{M}_{\mathrm{S}}$ 7.0; Suárez and Caballero-Jiménez, 2012), and 1912 Acambay earthquakes (M $\mathrm{M}_{\mathrm{S}} 6.7$; Suter et al., 1996) (Fig. 1). Such a study is fundamental as most of the population of Mexico lives within this region, in mega cities such as Mexico City (22 million inhabitants) and Guadalajara (5 million inhabitants), and is 
directly exposed to the potential seismic hazards related to this fault. Many of these large cities are located within active tectonic basins on lacustrine sediments and, thus, are likely to be affected by near or distant earthquakes, in particular if the resulting ground-shaking is being amplified by site effects (Campillo et al., 1989; Bayona Viveros et al., 2017).

Our objective in this study is to describe the seismic behavior of the fault zone to infer its parameters in order to improve, in further steps, the seismic hazard models of the region and enhance the awareness and preparedness of the Mexican population to the risks to which it is exposed.

\section{Geological setting}

\subsection{Neotectonic setting and seismicity}

The Trans-Mexican Volcanic Belt (TMVB) is a $900 \mathrm{~km}$ long and $200 \mathrm{~km}$ wide middle MioceneHolocene volcanic arc related to subduction along the Middle America trench and characterized by extensional arc-parallel faulting and related crustal seismicity (Ferrari et al., 2012). It crosses central Mexico from the Gulf of Mexico, on the east, to the Pacific coast, on the west (Fig. 1). In the central part of the belt, $<1 \mathrm{~km}$ of N-S to NNW-SSE oriented extension is distributed over a 30 to $50 \mathrm{~km}$ wide fault zone (Fig. 1). The bulk extension rate of the system is estimated to be $0.2 \pm 0.05 \mathrm{~mm} \mathrm{yr}^{-1}$ and the Quaternary vertical slip rates for individual fault average $0.07 \mathrm{~mm} \mathrm{yr}^{-1}$ (Suter et al., 2001).

The Acambay Graben is located in the central part of the TMVB and is defined by three main fault systems. The Acambay-Tixmadejé and the Epitacio-Huerta faults bound the graben to the north, while the Pastores fault and Venta de Bravo Fault (VBF) limit it to the south. Finally, the Temascalcingo and Acambaro fault systems dissect the central part of the graben (Figs. 1,2). 
The 1912, M 6.7 Acambay earthquake pointed to this graben as the closest crustal seismic source affecting Mexico City (Urbina and Camacho, 1913). Consequently, various studies were carried out to map the 1912 surface rupture and the main active faults in the graben (e.g., Urbina and Camacho, 1913; Mooser, 1972; Martínez-Reyes and Nieto-Samaniego, 1990; Suter et al., 1992, 1996, 2001; Rodríguez-Pascua et al., 2017). Pioneer paleoseismological studies in or near the epicentral area identified prehistoric large earthquakes and characterized the seismogenic potential of the two main bounding faults of the eastern part of the graben, the Acambay-Tixmadejé and the Pastores faults (Langridge et al., 2000, 2013; Ortuño et al., 2015), while other studies dealt with the paleoseismic history of the San Mateo and the Temascalcingo faults within the intragraben fault system (SunyéPuchol et al., 2015; Ortuño et al., 2018) (Figs. 1, 2).

Apart from the 1912 and the $1979, \mathrm{M}_{\mathrm{W}}$ 5.3 Maravatio earthquakes, the Acambay Graben is characterized by a low background seismicity level (Fig. 1). The 1956-2016 instrumental locations in the central TMVB show that most of the microseismicity is concentrated in the western Acambay Graben with a maximum depth of $15 \mathrm{~km}$, illustrating the thickness of the seismogenic layer (Fig. 1) (Rodríguez-Pérez and Zúñiga, 2017). The low magnitudes as well as the low density of seismological stations in the area make it impossible to calculate any focal mechanism of recent events.

The targeted fault in this work is the Venta de Bravo Fault. It is the longest fault bounding the Acambay Graben to the SW (Figs. 1, 2). Historical crustal earthquakes in 1734-35 and 1853-54 and instrumentally recorded seismicity including the February 22, 1979, $\mathrm{M}_{\mathrm{W}} 5.3$ Maravatio earthquake are probably associated with this fault (Orozco y Berra, 1887; Astiz-Delgado, 1980). The first event occurred in November 1734 and between November 1734 and March 1735, more than 30 strong and light earth tremors were felt in Tlalpujahua. The other event happened on January 13, 1854. A strong earthquake was felt in Tlalpujahua, Maravatío and San Juan del Río (68 km northeast of 
Maravatío), and in February and March of the same year many aftershocks were felt in the region (Suter et al., 1992). Based on these reports, these earthquakes could have been similar in size to the 1979 Maravatío earthquake and did not rupture the surface. Indeed, there is no surface rupture associated with the 1979 event, but its epicentral location north of the trace of the VBF, and its focal mechanism (normal faulting with a minor lateral component along the E-W oriented nodal plane) indicate that it is certainly associated with this fault (Astiz-Delgado, 1980; Suter et al., 1992) (Fig. $1)$.

\subsection{Structure, morphology and segmentation of the Venta de Bravo Fault}

Structural studies from Suter et al. $(1992,1995)$ indicate at least two stages of deformation along the southern graben border faults; a Miocene early-stage of oblique right-lateral extension results in a left-stepping en echelon array of NW-SE striking normal fault segments and a later Pliocene stage, which continues to the present, corresponds to a dominant normal dip slip movement with a minor left lateral component resulting from a N-S to NNW-SSE orientation of crustal extension (Fig. 1). These different stages of deformations result in a complex geometry of the fault trace.

The VBF scarp extends E-W nearly $48 \mathrm{~km}$, from the San Andres volcano to the Cachiví River plain (Fig. 3). It represents the southwestern boundary of the Acambay Graben and the northern boundary of the hilly region surrounding Tlalpujaua and El Oro de Hidalgo. The VBF is discontinuous and is divided in three main segments.

The Eastern VBF segment is composed of two parallel fault branches $2 \mathrm{~km}$ apart and oriented W-E to WNW-ESE. The northern strand ( $\mathrm{n}^{\circ} 1$ and 2 in Fig. 3) extends $21 \mathrm{~km}$, from the San Andres volcano to the Venta de Bravo village, with a scarp height of 40-190 $\mathrm{m}$ in Pliocene volcanic formations (Fig. 2; profiles $\mathrm{H}$, I and $\mathrm{J}$ in Fig. 3). According to classical scaling relationships (Wells 
and Coppersmith, 1994), such a normal fault could cause $\mathrm{M}_{\mathrm{W}} 6.6 \pm 0.3$ earthquakes when rupturing entirely. The southern strand ( $\mathrm{n}^{\mathrm{o}} 3$ in Figs. 2,3$)$ is developed on the up-thrown block of the northern strand, has a total length of $10 \mathrm{~km}$ and a scarp height of $60-80 \mathrm{~m}$ affecting Miocene to Pliocene volcanic deposits (Fig. 2; profiles $\mathrm{H}$ and I in Fig. 3). Its proximity to the main VBF (2 km) and consistent dips suggest that the two fault branches connect at depth and are the expression of a single fault at the surface.

The Central VBF segment ( $\mathrm{n}^{\circ} 4$ in Figs. 2,3) is $18 \mathrm{~km}$ long with maximum scarp heights $>200 \mathrm{~m}$ in Pliocene volcanic rocks (Fig. 2; profiles F and G in Fig. 3). Such a normal fault could cause $\mathrm{M}_{\mathrm{W}}$ $6.5 \pm 0.3$ earthquakes when rupturing entirely (Wells and Coppersmith, 1994). At its easternmost end, the fault overlaps and connects with the Eastern VBF segment.

The Western VBF segment ( ${ }^{\circ}$ 5, 6, 7 and 8 in Figs. 2, 3) is $26 \mathrm{~km}$ long and separates Miocene to Quaternary andesitic lavas to the south from younger fluvial deposits to the north. Its morphology varies from east to west and its scarp height ranges from 50 to $300 \mathrm{~m}$ (profiles $\mathrm{C}$ to $\mathrm{F}$ in Fig. 3). Such a fault segment could cause $M_{\mathrm{W}} 6.7 \pm 0.3$ earthquakes when rupturing entirely (Wells and Coppersmith, 1994).

In addition to this main segment, three shorter (4 to $10 \mathrm{~km}$ ) secondary fault scarps affect Pliocene lava domes and surrounding landscape both within the hanging and foot walls ( $\mathrm{n}^{\circ}$ 6, 7 and 8 in Fig. 3). These faults are considered as branches, probably merging at depth with the main VBF. They display vertical scarps reaching up to $130 \mathrm{~m}$ height in the Pliocene lava and less than $20 \mathrm{~m}$ high on the Cachiví River plain (profiles A to D in Fig. 3). The cumulated observed displacement of parallel branches of the Western VBF segment is about $400 \mathrm{~m}$, which is the "apparent" vertical offset. The actual vertical displacement could be substantially larger, and constrained through detailed mapping 
of the base of the Pliocene volcanic bodies under the Quaternary sedimentary infill in the downthrown block.

Furthermore, structural and geomorphological studies (Suter et al., 1992, 1995, 2001; Langridge et al., 2013; Ortuño et al., 2015) suggest that the VBF and the Pastores fault might be a same fault system (Figs. 1, 2). The whole system Pastores-VBF is approximately $80 \mathrm{~km}$ long at the surface (Fig. 2) and could cause major earthquakes when rupturing entirely.

\section{Methods}

Three sites (Terreros, Guapamacataro and Campo Hermoso) were selected according to a preliminary geomorphic analysis of the landscape after aerial photoreconnaissance and field inspection (Fig. 4). Three trenches by sites were dug with a backhoe excavator perpendicularly to the inferred fault trace. Each excavation was between 10 and $30 \mathrm{~m}$ long and 2 to $3 \mathrm{~m}$ deep exposing well-preserved and moderate-height geomorphic fault scarps (Figs. 4, 5). Only five out of nine trenches provided relevant information (red labels in Fig. 4).

Classical methods of paleoseismic survey across normal fault scarps (e.g., Audemard, 2005; McCalpin, 2009) were used. A detailed description of the sedimentary facies, composition and mineralogy combined with the dating of samples from each unit allowed us to infer the stratigraphic correlations within and between trenches. A total of 24 samples from the five trenches yielded radiocarbon ages. They were processed at three different laboratories by conventional dating and accelerator mass spectrometry (AMS) methods (Table 1). Radiocarbon ages were calibrated without taking into account the stratigraphic order, using the OxCal 4.1 program (Bronk Ramsey, 2009) and resulting ages are presented at the 2 sigma confidence level (Table 1), and expressed in calibrated years before present (cal. BP). As usual in paleoseismological studies, ages are expressed as 
conventional radiocarbon ages in the description of the results and trench log figures, while calibrated ages are only used in the discussion. In the same way, the seismic events identified in the different trench sites are exposed from the youngest to the oldest, in order to subtract, for each event, the effects of later ruptures.

Below, results are presented on a site-by-site basis from E to W (i.e., Terreros, Guapa and Hermoso Trench sites), as shown by the overview pictures and the trench logs (Figs. 4-8).

\section{Results and analyses: trench survey}

\subsection{Depositional context}

The study focused on the Western VBF segment because it is where the fault intersects the youngest deposits of the area (Upper Pleistocene and Holocene), with potentially resolved stratigraphy (alluvium and/or volcanic layers), therefore allowing us to make an estimation of the recent earthquake history of the fault system. A detailed stratigraphic analysis was carried out at five trenches located in the alluvial plains of the Cachiví River and close to Terreros dam (Fig. 4).

The Upper Pleistocene-Holocene sedimentation at the Western VBF segment is driven by various factors and sources that prevent clear stratigraphic correlation of the depositional units between sites (Fig. 4). At the Terreros site, the erosion of the dacitic dome formed colluvial deposits that prograded on a fluvio-lacustrine plain. The Guapa Site is located on the alluvial plain of the Cachiví River where epiclastic volcanic deposits and alluvial sediments overlay volcanic bedrock. Finally, the Hermoso site is located on a former alluvial plain filled by volcanic deposits and detritic flows from the south and elevated $20 \mathrm{~m}$ with respect to the current Cachiví River plain.

\subsection{Terreros trench site}


The Western VBF segment offsets the lava flows of the San Miguel volcanic complex, and displays a sinuous trace (Figs. 3, 4). Between the volcanic edifices of San Miguel to the east and the El Jaguiey cinder cone to the west, a depression has been generated in the down-thrown block, occupied today by the Terreros dam and an agricultural plain (Figs. 4, 5). The main fault scarp has a $>200 \mathrm{~m}$ throw at this site and presents a curved geometry. Secondary fault branches were observed in the down-thrown block, with smooth and low elevation $(<2 \mathrm{~m})$ associated scarps that displace the surface of an alluvial fan (Fig. 4). We excavated one trench across the main fault segment without conclusive results (Terreros 3 in Fig. 4D) and two trenches, about $280 \mathrm{~m}$ apart, across these secondary morphological scarps. These last two trenches were 24 and $30 \mathrm{~m}$ long, and $3 \mathrm{~m}$ deep (Terreros 1 and 2 in Fig. 4D) but only Terreros 1 showed faulted units.

\subsubsection{Terreros 1 trench stratigraphy}

Five units were exposed in Terreros 1 (Fig. 6). Their stratigraphy is described in detail in Table 2 and summarized in the following. The two basal units are ignimbrites (Units E and D). Unit D might be considered as the upper part of Unit E, since the transition from one to the other is gradual. They are overlain by two debris flow deposits (Units C and B). In the southern part of the trench, Unit $\mathrm{C}$ is covered by the thinner Unit C' corresponding to a final deposit segregated from Unit C. Unit B is only observed closer to the geomorphological scarp. The top Unit A is interpreted as a colluvial slope deposit generated by the wash-out of the finer components of the up-thrown block of the fault. Units A and B incorporate two large and subspherical blocks (up to $2.2 \mathrm{~m}$ diameter) that likely correspond to blocks of rock fallen from the scarp and deposited during or immediately after Unit B. Only two samples of charcoal from Units A and C yielded ages at that site (Table 1).

\subsubsection{Faulting}


A number of N070E to N080E oriented vertical faults and fractures affecting all units except the uppermost one (Unit A) were exposed in the trenches (Fig. 6). F8 and F9 vertically displace Units D and $\mathrm{E}$ with a maximum offset of $12 \mathrm{~cm}$, since $\mathrm{F} 1$ to $\mathrm{F} 4$ show vertical offsets of almost $20 \mathrm{~cm}$. The spatial coincidence of F4 with respect to the position of the larger boulder (columns 15-17) suggests that the geometry of the layers have been disturbed by the impact of the block that fell from the 200 m high main fault scarp (Fig. 3). Colluvial layers related to the erosion of an earthquake scarp (colluvial wedge), like commonly identified along dip-slip faults (McCalpin, 2009) and like those shown below at the Guapa site, were not observed at this site. We could only use the upward faulttermination beneath dated stratigraphic layers to infer the faulting events (Fig. 6). The youngest event (Tr.1) is constrained by Units A (not affected) and B (last affected) and is obvious in the fault zone F1a-F2a. The previous event (Tr.2) is located at the base of Unit C, which is not affected by the faults exposed in the northern part of the trench (F6a, F7a and F9a). The scarcity of dating results produces a large uncertainty in constraining the age range of the events: Tr. 1 occurred between 10,090 $\pm 130{ }^{14} \mathrm{C}$ yr BP (age of Unit C') and $2980 \pm 85{ }^{14} \mathrm{C}$ yr BP (age of Unit A), while Tr.2 was older than $10,090 \pm 130{ }^{14} \mathrm{C}$ yr BP.

\subsection{Guapa trench site}

The Guapa site is located near the village of Guapamacataro, ca. $6 \mathrm{~km}$ southeast of Maravatío, and next to the intersection of the Cachiví River with the fault (Fig. 4). This area was selected because the Venta de Bravo main fault scarp presents a clear morphological expression and intersects the alluvial plain, is crosscut by the river and sealed by younger alluvial deposits, and has less geomorphological expression (1 to $3 \mathrm{~m}$ high) in the vicinity of the river, so that preserved young sediments were expected to show evidence of the latest earthquakes. 
Three trenches, located in the Cachiví floodplain and containing a relatively complete recent sedimentary record, were dug at this site (Fig. 4C). They are named Guapa 1,2 and 3 and are $30 \mathrm{~m}$ E, $120 \mathrm{~m} \mathrm{~W}$ and $170 \mathrm{~m} \mathrm{~W}$ of the Cachiví riverbed, respectively (Fig. 5A, 5B). Guapa 1 exposed at least $2 \mathrm{~m}$ of sub-actual flood deposits within which no recent deformation could be identified, while more stratigraphic units were preserved in Guapa 2 and Guapa 3. Twelve charcoal and bulk soil samples were collected in both trenches for radiocarbon dating (Table 1). The resulting ages are consistent with the stratigraphy and can be reasonably interpreted as depositional ages.

\subsubsection{Guapa trench stratigraphy}

The Guapa trenches exposed (1) fluvio-lacustrine deposits, (2) volcanic or reworked volcanic layers, and (3) paleosols that are described in detail in Table 2. Most units were easily correlated between both trenches (Fig. 7, Table 2). The oldest deposits correspond to an andesitic lava flow (Unit $\mathrm{H}$ ) and are only seen in Guapa 2. The overlying Unit $\mathrm{G}$ is a sequence of yellow massive ignimbrite (possibly reworked). Unit $\mathrm{F}$ is a reworked yellow ignimbrite only visible in Guapa 3, where its base is not exposed and its top is eroded. All other overlying units are clearly exposed in both trenches and correspond to epiclastic volcanic deposits, fluvial deposits and soil. Unit $\mathrm{E}$ is an ash-rich paleosol. Excavation of a test pit near Guapa 3 (location in Fig. 5C) indicates that Unit E is also present near the surface on the footwall of the fault. Unit D lies unconformably on Unit E and corresponds to a thick colluvium deposit. Between both units we identified two colluvial wedges. The lower one, CW1, is mainly composed of fragments of Unit G in a brown clay matrix. The upper one, CW2, is composed of undifferentiated angular andesitic fragments in a yellow-brown clay matrix. Unit D and CW2 are mainly distinguished using the color and matrix composition. The top of Unit D is eroded and unconformably covered by Unit C, a dark brown paleosol. Unit B is a pale brown paleosol, overlain by Unit A, the present soil. 


\subsubsection{Faulting}

Apart from top Units A and B, all units are faulted at both trenches. Four and five N085E to N100E oriented faults are exposed in Guapa 2 and Guapa 3, respectively. The main fault, F1, dips $70^{\circ}-80^{\circ}$ to the $\mathrm{N}$ and displaces all the units deposited before Unit B (Fig. 7). The other faults correspond to branches of secondary faults and are labeled F2a, F3a and F4a at Guapa 2 and F2b, F3b, F4b and F5b at Guapa 3; the damage zone width spans from 3 to $5 \mathrm{~m}$. F3a, F4a and F5b are located in the hanging wall formed by the main fault F1. At Guapa 2, F3a and F4a are small normal faults, synthetic to F1 and partially inverted by the decrease of the vertical stress at the surface. F3a displaces Units E and lower units, and F4a reaches Unit C. At Guapa 3, F5b could correspond to a wall of a fracture opening along F1 or to the limit of an altered area along the main fault zone without clear displacement. At both trenches, F2a, F2b, F3b and F4b fracture the footwall. These faults clearly displace Unit G and some younger units above it. Finally, at Guapa 3, Units G, F and E are clearly faulted and folded at the vicinity of F1. This folding of Unit G, whose S0 is nearly parallel to the $\mathrm{F} 1$ fault plane, is interpreted as a draping fault process at the beginning of the deformation of Unit G. Open fractures were also observed within Unit G.

Four events, Ga.1 to Ga.4 from youngest to oldest, were inferred at the Guapa site. The youngest event, Ga.1, faulted (and maybe folded?) Unit C and underlying units without affecting Unit B along the main fault F1 and related F2a, F4a, F3b. By measuring the offset of the base of Unit C along F1 on Guapa 3 western wall, a minimum vertical slip of $18 \pm 2 \mathrm{~cm}$ was calculated for this event that occurred after the deposition of Unit $\mathrm{C}\left(130 \pm 30\right.$ to $\left.935 \pm 30{ }^{14} \mathrm{C} \mathrm{yr} \mathrm{BP}\right)$ and before Unit $\mathrm{B}\left(175 \pm 30{ }^{14} \mathrm{C}\right.$ yr BP $)$.

A previous event, Ga.2, faulted the colluvial wedge 2 (CW2) without affecting Unit D. A minimum displacement of $35 \pm 5 \mathrm{~cm}$ was inferred by measuring the offset of the base of CW2 along fault F1 on Guapa 3 eastern wall. The geometry of the colluvial wedge indicates that its uplifted part was 
probably eroded before the deposition of Unit D. This event occurred after the deposition of CW2 $\left(2305 \pm 30{ }^{14} \mathrm{C}\right.$ yr BP $)$ and before Unit D $\left(1460 \pm 30{ }^{14} \mathrm{C}\right.$ yr BP $)$.

The colluvial wedge CW2, identified in both trenches, corresponds to an earlier event, Ga.3. The vertical displacement associated with this event is impossible to measure due to the lack of preservation of the units on the footwall. However, it can be roughly inferred from the thickness of the colluvial wedge (McCalpin, 2009). Here, the 30-40 cm thick colluvial wedge would correspond to a minimum vertical slip of $60-80 \mathrm{~cm}$ for event Ga.3, which occurred just before the deposition of CW2 $\left(2305 \pm 30{ }^{14} \mathrm{C}\right.$ yr BP $)$.

Events Ga.4 corresponds to the formation of the CW1, a colluvial wedge composed of angular clasts of Unit G formation in a clay matrix. CW1 has been recognized in both trenches, although with some uncertainty in Guapa 2, and indicates that Ga.4 occurred after the deposition of Unit E $\left(7365 \pm 35{ }^{14} \mathrm{C}\right.$ yr BP$)$ and before the formation of CW2 $\left(2305 \pm 30{ }^{14} \mathrm{C}\right.$ yr BP $)$. Using the McCalpin (2009) relation between displacement and colluvial wedge thickness, the 40-60 cm thick CW1 would correspond to a minimum vertical slip of $80-120 \mathrm{~cm}$ for event Ga.4. An older event could be deduced from fracture fillings in older formations. However, the poor preservation of the oldest units on either side of the fault zone makes it impossible to characterize them with certainty.

\subsection{Hermoso trench site}

The Hermoso site is located near the village of Campo Hermoso, ca. $6 \mathrm{~km}$ southwest of Maravatio (Fig. 4). We excavated three trenches (Hermoso 1, 2 and 3) at the western end of the fault, where the scarp was inferred from a smooth inflection of the surface. The trenches, 80 and $150 \mathrm{~m}$ from each other on the same volcanic-fluvial surface (Fig. 4), were $12 \mathrm{~m}$ long and approximately $3 \mathrm{~m}$ deep (Fig. 5E). Hermoso 3 exposed an approximately $3 \mathrm{~m}$ deep buried cave at the fault. Volcanic 
deposits sealing the fault attested to its inactivity during the last ruptures. Therefore, Hermoso 3 was not incorporated in the paleoseismological analysis. Hermoso 1 and 2 show intensely deformed stratigraphic units, with faults and largely opened fractures. Nine soil samples were collected from both trenches for radiocarbon dating (Table 1), with the ages in stratigraphic order.

\subsubsection{Hermoso trench stratigraphy}

The Hermoso trenches exposed volcanic deposits or epiclastic volcanic deposits, sediments and soils rich in volcanic material (Fig. 8). Their stratigraphy is described in detail in Table 2 and summarized in the following. The Quaternary volcanism has not been described in this area, and the age and provenance of volcanic formations observed in the trenches are unknown. Several units were easily correlated between the trenches (Units I, F, C, B, A). The oldest exposed formation (Unit I) is a lava flow. At Hermoso 1, Unit I is unconformably overlain by Unit $\mathrm{H}$, a brown clay interpreted as an epiclastic deposit. Unit $\mathrm{H}$ is overlain by lapilli and pumice deposits (Units $\mathrm{G}$ and F). Unit $\mathrm{F}$ is the oldest unit above Unit $\mathrm{I}$ that can be correlated between the two trenches. Unit $\mathrm{E}$ and D are only preserved at Hermoso 2 and are an epiclastic volcanic deposit and a debris flow deposit (eroded on top), respectively. The three younger units are visible in both trenches. Unit $\mathrm{C}$ is interpreted as an epiclastic ash deposit, eroded on top and unconformably covered by Unit B, which corresponds to weathered ash deposits or to epiclastic volcanic deposits. Unit B is overlain by the present black soil, Unit A.

\subsubsection{Faulting}

Apart from the present soil (Unit A), all units are faulted at both trenches. A total of 13 and 12 faults were exposed at Hermoso 1 and Hermoso 2, respectively. The main fault, indicated as F1b at Hermoso 2, is oriented N070-080E, dips $70^{\circ}-80^{\circ}$ to the $\mathrm{N}$ and offsets all the units deposited 
previously to Unit A (Fig. 8). At Hermoso 1, we did not identify any fault with such a displacement and assumed that the main fault must be located south of the trench. The other secondary faults, located on the hanging wall of the main fault, are called F2a to F13a at Hermoso 1 and F2b to F12b at Hermoso 2. Most secondary faults correspond to filled open fractures with or without associated vertical displacement.

Six events, Hr.1 to Hr.6 from youngest to oldest, were inferred at this site (Fig. 8). The youngest event, Hr.1, faulted all the units except Unit A along F1b, F2a, F4a, F5a and F6a. A minimum vertical slip of $16 \pm 2 \mathrm{~cm}$ was calculated by measuring the offset of the base of Unit B along F1b at Hermoso 2. This event occurred after the deposition of Unit B $\left(3830 \pm 30{ }^{14} \mathrm{C}\right.$ yr BP $)$ and before Unit A (present soil).

Event Hr.2 activated most of the faults observed at both trenches and corresponds to the opening of fractures affecting all units previous to Unit B (along faults F2a to F6a, F8a to F10a, F2b, F12b). The following erosive event is highlighted by the angular unconformity at the base of Unit B. Due to this erosion, it is not possible to calculate the displacement associated with the event at Hermoso 1. However, it could be greater than $100 \mathrm{~cm}$ if we consider the shifting along fault F1b at Hermoso 2. The cumulative displacement associated with this event along the secondary faults (e.g., F9a, F10a; i.e., 30-40 cm) confirms that the movement was certainly important along the main fault. This event occurred after the deposition of Unit C $\left(5185 \pm 30\right.$ to $\left.6360 \pm 35{ }^{14} \mathrm{C} \mathrm{yr} \mathrm{BP}\right)$ and before Unit B $\left(3830 \pm 30{ }^{14} \mathrm{C}\right.$ yr BP $)$.

Event Hr.3 corresponds to the opening and filling of a fracture (F3b-F4b) and a $5 \mathrm{~cm}$ vertical displacement along F11b. Other possible evidence of Hr.3 is given by the displacement of Unit D (debris flow deposit) and the fracture-filling between faults F1b and F2b at Hermoso 2. There, the geometry of Unit C seems related to the earthquake rupture, filling the topography formed during 
the event. Of the over $200 \mathrm{~cm}$ of displacement of Unit D along F1b, $116 \mathrm{~cm}$ are related to the event Hr.1 and Hr.2, and $84 \mathrm{~cm}$ could be related to Hr.3. However, this estimation must be considered hypothetical since later processes have erased evidence of the measurable displacement attributed to Hr.3. Event Hr.3 occurred after the deposition of Unit D $\left(8575 \pm 35{ }^{14} \mathrm{C}\right.$ yr BP $)$ and before Unit C $\left(5185 \pm 30\right.$ to $6360 \pm 35{ }^{14} \mathrm{C}$ yr BP $)$.

Event Hr.4 is observed in Hermoso 2 along F5b and F8b to F11b, displacing Unit E before the deposition of Unit D. At Hermoso 1, an intermediate unit (columns 1 and 2) has been interpreted as a colluvial wedge related to an assumed major fault located to the south and not exposed in the trench. The main evidence is that its location is restricted to the fault zone, and that its texture is made of angular clasts from the underlying unit (lava fragments from Unit I). Due to the lack of piercing points, it is not possible to calculate precisely the event displacement, but using the McCalpin (2009) relation between displacement and colluvial wedge thickness (40 to $50 \mathrm{~cm}$ ), we would obtain a minimum vertical slip of $80-100 \mathrm{~cm}$. The different dating results indicate that the event occurred after the deposition of Unit E $\left(19,930 \pm 100{ }^{14} \mathrm{C} \mathrm{yr} \mathrm{BP}\right)$ and before Unit D (8575 \pm $35{ }^{14} \mathrm{C}$ yr BP). The colluvial wedge allows a better constraint of the event, probably occurring at $8680 \pm 40{ }^{14} \mathrm{C}$ yr BP.

Event Hr.5 has only been recognized at the bottom of Hermoso 2 and corresponds to displacement along F6b and F7b. Due to the unavailability of measurable markers, it is not possible to calculate the displacement related to that event, which occurred just before the deposition of Unit E $(19,930 \pm$ $100{ }^{14} \mathrm{C}$ yr BP) and after Unit E'.

The oldest event identified is Hr.6, which is illustrated, at Hermoso 1, by two fault zones along F7a and F11a. It occurred just after the deposition of Unit G and before Unit F. There was no suitable material for dating, but this event must be much older than Unit E $\left(19,930 \pm 100{ }^{14} \mathrm{C} \mathrm{yr} \mathrm{BP}\right)$. 


\section{Discussion}

\subsection{Paleoearthquake history of the western segment of the Venta de Bravo Fault}

In this section we analyze and compare the timing of the events observed in the five trenches, distributed on three sites along the Western VBF segment. The ultimate goal is to estimate the recurrence interval of surface faulting on this segment. For clarity and following the approach proposed by Ortuño et al. (2012), the term "paleoearthquake" (PE) refers to the paleoseismic events deduced from the correlation between the different trenches sites, while the term "event" designates individual events described at each site. The timing of the "events" and the related "paleoearthquakes" was obtained based on 23 radiocarbon dates (Table 1) and summarized in Fig. 9 using 2-sigma level of calibration uncertainty. In the following discussion, the age of units and events corresponds to calibrated ages BP.

At Terreros site, two events have been identified (Fig. 6) along a secondary fault, parallel to the VBF main fault (Tr.1 and Tr.2). However, due to the lack of sedimentary record and radiocarbon dates, these two events are poorly constrained (Fig. 9). At the Guapa site, four well-dated events younger than 8315 cal. yr BP were recorded in both trenches (Ga.1 to Ga.4) (Figs. 7, 9). At the Hermoso site, six events were recorded in two trenches (Fig. 8), but only four of them are well dated (Hr.1 to Hr.4). The two older events (Hr.5 and Hr.6) precede 24,268 cal. yr BP. The recent sedimentary record at this site is quite poor with only two units younger than 4406-4102 cal. yr BP, including the present-day soil. Accordingly, event Hr.1 may correspond to one or all of the three most recent events (Ga.1 to Ga.3) identified at the Guapa site (Fig. 9). Considering the uncertainties on the ages of the events and the quality of the sedimentary record at the three sites, the Guapa site has been taken as a reference for events post-dating 8315-8046 cal. yr BP and the Hermoso site as a reference for older events for the identification and characterization of the paleoearthquakes (Fig. 
9).

The correlation of events allows us to infer at least eight paleoearthquakes. This estimation must be considered as a minimum since it is not certain whether all earthquake ruptures were recorded in the sedimentary material. Furthermore, the deformation attributed to a single event could also result from successive events as illustrated by event Hr.1 that might correspond to events Ga.1, Ga.2 and Ga.3.

The eight paleoearthquakes identified are (Fig. 9):

(1) Paleoearthquake 1 (PE 1) corresponds to event Ga.1, recorded in the Guapa 2 and 3 trenches but not identified at the others sites (although perhaps Hr.1 at the Hermoso site). This event is historical and occurred between 924 and 34 cal. yr BP according to radiocarbon dating. In this area the historical earthquake record seems to be reliable only since the 18th century (García Acosta and Suárez Reynoso, 1996). Since that time, historical crustal earthquakes in 1734-35 and 1853-54 and instrumentally recorded seismicity including the February 22, 1979, $\mathrm{M}_{\mathrm{W}}$ 5.3 Maravatío earthquake are probably associated with this fault but did not rupture the surface. Therefore, PE1 could have taken place between 924 and 250 cal. yr BP.

(2) Paleoearthquake 2 (PE 2) corresponds to event Ga.2, it could also fit Hr.1 and occurred between 2359 and 1302 cal. yr BP.

(3) Paleoearthquake 3 (PE 3) corresponds to event Ga.3 and could also match Hr.1. It is well dated and should be slightly younger than 2359 cal. yr BP, the date obtained for the colluvial wedge associated to the event (Unit CW2 in Fig. 7). 
(4) Paleoearthquake 4 (PE 4) corresponds to event Hr.2 and could also correlate to events Ga.4 and Tr.1, which are not so well dated. This event occurred between 7419 and 4102 cal. yr BP.

(5) Paleoearthquake 5 (PE 5) corresponds to event Hr.3 and could also match Ga.4 and Tr.1, which are not so well dated. This event occurred between 9597 and 5909 cal. yr BP.

(6) Paleoearthquake 6 (PE 6) corresponds to event Hr.4 and could also match Tr.1 or Tr.2. It occurred between 24,268 and 9491 cal. yr BP. A colluvial wedge yields an age of 9737-9543 cal. yr BP, indicating that the event has probably occurred slightly before the formation of the wedge.

(7) Paleoearthquake 7 (PE 7) corresponds to event Hr.5 and could also fit Tr.2 that is not well dated. It has been only identified in trench Hermoso 2 and occurred just before the formation of Unit E, dated at 24,268-23,691 cal. yr BP.

(8) Paleoearthquake 8 (PE 8) corresponds to event Hr.6. It is only observed in Hermoso 1 and there is no date for this event, although it is inferred that it occurred before PE 7.

The synthesis of the identified paleoearthquakes reflects the heterogeneity of the sedimentary record over time (Fig. 9). Trenches at the Guapa site exposed a recent sedimentary record that preserves the evidence of the events occurring between 8315-8046 cal. yr BP and the present. At the Hermoso trenches, the analyzed units are older and provide evidence for earthquakes that occurred between 9737-9543 cal. yr BP and 4406-4102 cal. yr BP. The sedimentary record of the oldest earthquakes (PE 7 to PE 8) is not well preserved resulting in poor bracketing of their ages in all trenches. Thus, the interpretation of their recurrence interval is highly speculative. For example, should Tr.2 be 
considered together with Hr.5 as describing PE 7 or should they be considered as two independent events?

Consequently, the recurrence interval of surface faulting is ca. 2000-2390 yr if calculated according to the last five paleoearthquakes interpreted along the western segment of the VBF (PE 1 to PE 5). Including PE 6 in the calculation and considering the age of the colluvial wedge as the age of this event, the recurrence interval for the last six paleoearthquakes is $1940 \mathrm{yr}$. The lack of evidence of Holocene events between events PE 4 and PE 3 suggests that the fault does not rupture periodically, in agreement with other observations of the central TMVB (Ortuño et al., 2018).

This recurrence interval is in agreement with the range estimated at the junction between the Pastores fault and VBF (1.1-2.6 kyr; Ortuño et al., 2015). In contrast, Langridge et al. (2013) proposed return intervals for the Pastores fault ranging between 10 and $15 \mathrm{kyr}$ (Table 3). The difference could be due to the incompleteness of the sedimentary record in Langridge et al. (2013) study (some events were not recorded) or that the central Pastores trenches were excavated on a secondary fault segment. Both hypotheses are supported by the lack of evidence of the 1912 earthquake at trenches across the central Pastores Fault (Langridge et al., 2013).

\subsection{Single-event displacement and magnitude relations}

In addition to the chronology of the paleoearthquakes, the amount of slip per event and the maximum expected magnitude are essential to characterize the seismic behavior of a fault and its seismic hazards. The vertical slip per event calculated for the Western VBF segment ranges between $18 \mathrm{~cm}$ (PE 1) and more than $100 \mathrm{~cm}$ (PE 4, Fig. 9) with an average slip of ca. $45 \mathrm{~cm}$. These values for the VBF should be taken as minima, because they are calculated at the western tip of the fault, and they do not include potential slip accommodated by other fault segments (i.e., fault segments 6 , 
7 and 8 in Fig. 3). They are however in agreement with those reported in other paleoseismological studies within the Acambay Graben, which range between 29 and $194 \mathrm{~cm}$ (Langridge et al., 2000, 2013; Sunyé-Puchol et al., 2015; Ortuño et al., 2015, 2018) (Table 3). If we assume 18-100 cm slip per event to be a representative value of the minimum average displacement along the VBF, it corresponds to earthquakes with a magnitude between 6.3 and 6.9 , according to the Wells and Coppersmith (1994) scaling relationship for normal faults. Considering the uncertainties about the amount of slip per event at the western tip of the fault, another way to estimate the maximum expected magnitude is based on the total fault length (Wesnousky, 2008). We consider two different lengths; the $26 \mathrm{~km}$ long Western VBF segment and $48 \mathrm{~km}$ VBF total length (Fig. 3). The Wesnousky (2008) relationship, scaled for normal faults and crust thicker than $10 \mathrm{~km}$, gives us a magnitude that varies from $\mathrm{M}_{\mathrm{W}} 6.8$, for the western segment, to $\mathrm{M}_{\mathrm{W}} 6.9$, for the total fault length. Using the fault length, considered as more reliable (Stirling et al., 2002, 2013), the estimated magnitudes are in the high range compared to those obtained using displacements observed in trenches. Accordingly, some of the vertical displacements should be considered as minima, which is acceptable since some of the trenching sites are located at the tip of the fault.

\subsection{Slip rate of the western segment of the Venta de Bravo Fault}

The amount of displacement measured in the trenches leads to an estimate of the minimum slip rate along the western segment of the VBF. In order to calculate it with the lowest uncertainties we focus on the main fault in trenches Guapa 3 and Hermoso 2, which present the most continuous sedimentary sequence. At Guapa 3, a test pit (Location on Fig. 5C) highlighted the presence of Unit $\mathrm{E}$ as a relic on the footwall. Assuming that Unit E was deposited horizontally across the fault and later offseted, there is ca. $1.9 \mathrm{~m}$ minimum vertical displacement on the top of Unit E. Knowing the age of Unit E (8315-8046 cal yr BP) we estimate a minimum dip-slip rate between 0.22 and 0.24

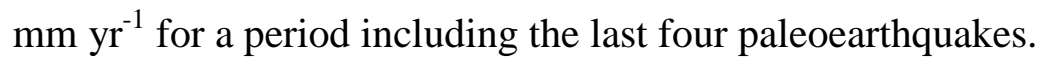


At the Hermoso site, the two reported trenches are characterized by a series of largely open fissures within the volcano-sedimentary deposits (Fig. 8). They accommodate an almost pure tensile stress, normal to the fracture walls, and the amount of opening reveals a relatively large cumulative stretching, compared with the deformation observed at the Guapa trenches. Such similar largely open fissures were also observed along an intragraben fault on the Temascalcingo volcano after the Acambay 1912 earthquake (Urbina and Camacho, 1913) and interpreted as induced by ground shaking (Langridge et al., 2000). Thus, part of the deformation observed in both trenches at the Hermoso site and attributed to Hr.2 and Hr.3 might partially correspond to co-seismic gravitational sliding events instead of pure tectonic events.

At the Hermoso 2 trench, the only clearly offset level (whose age is unknown), is Unit I around F1b, F2a and F3a (Fig. 8). Assuming that Unit D was deposited on both sides of the fault, ca. 160 cm of minimum vertical displacement is measured at the top of Unit D (9597-9491 cal. yr BP). Thus, a minimum dip-slip rate for Hermoso 2 is ca. $0.17 \mathrm{~mm} \mathrm{yr}^{-1}$ during a period that includes the five last paleoearthquakes. However, taking into account that we have only found evidence of three events at this site during the last $9.5 \mathrm{kyr}$ and that the site is located at the western termination of the fault, we should expect a higher slip rate in the central part of the fault. In any case, given the uncertainties regarding the origin of the displacement and the poor preservation of younger units on the footwall at the Hermoso site, the tectonic displacement measured is uncertain. Accordingly, the slip rate of $0.22-0.24 \mathrm{~mm} \mathrm{yr}^{-1}$, calculated on the Guapa 3 trench, corresponds to a more complete paleoearthquake record and better represents the slip rate of this fault. All these values are calculated taking into account vertical displacement and without considering strike-slip component. Indeed, in the western VBF, fault plane striation inversion and volcanic alignments indicate a NNW-directed extension, locally perpendicular to the strike of the fault (Suter et al., 1992, 1995) (Fig. 1). However, if there is a strike-slip component of movement, it is necessarily minor as it is 
not preserved in the Holocene cumulated geomorphic signal.

These new slip rates are somewhat higher but comparable to those, ranging between 0.03 and 0.17 $\mathrm{mm} \mathrm{yr}^{-1}$, deduced from paleoseismological analyses on faults of the eastern Acambay Graben (Langridge et al., 2000, 2013; Sunyé-Puchol et al., 2015) (Table 3) and are also greater than the 0.17-0.18 $\mathrm{mm} \mathrm{yr}^{-1}$ maximum vertical slip rates for the Quaternary faults in the central TMVB estimated by Suter et al. (2001). Only Ortuño et al. (2015) calculate a higher slip rate of 0.23-0.37 $\mathrm{mm} \mathrm{yr}^{-1}$ for the past $\sim 6-4 \mathrm{kyr}$ and state that prior estimated slip rates should be considered as minimum values because some studies calculate a low slip rate on only one segment of a fault system, in an area where the deformation could be distributed over several fault segments, and the sedimentary and therefore paleoseismological record may be incomplete. In this context, the slip rate calculated here, a little higher than the average, could be related to a better record of the Holocene paleoearthquakes and could therefore better reflect the Holocene slip rate than previous studies. In that case, the slip rate along some faults of the eastern Acambay Graben might be higher than previously calculated.

Another explanation might be that in the western part of the Acambay Graben, the tectonic strain is more concentrated on some particular faults (e.g., the VBF), whereas in the eastern Acambay Graben the strain is distributed in a larger number of faults. This second hypothesis needs to be explored through systematic transect studies of the western Acambay Graben faults.

\subsection{Seismic hazards posed by the Venta de Bravo Fault}

Overall, the results of this study highlight the VBF as an active fault capable of generating damaging earthquakes. We have presented evidence for at least eight paleoearthquakes closely spaced in time (1.9-2.3 kyr), whose strain would be released by moderate to large earthquakes of 
magnitude $\left(\mathrm{M}_{\mathrm{W}}\right)$ 6.8-6.9. In addition, the recurrence interval calculated for the VBF is two times shorter than that of the Acambay-Tixmadejé Fault and four to eight times shorter than those of the other faults studied in the graben (Table 3) (Langridge et al., 2000, 2013; Ortuño et al., 2015; Sunyé-Puchol et al., 2015). All these fault parameters point to the VBF as the major seismic source in the Acambay Graben. Until now, seismic hazard assessment studies on a national scale have only considered the effect of instrumental and historical seismicity on ground acceleration (Shedlock et al., 2000; Giardini et al., 2003; Tena-Colunga et al., 2009; Bayona Viveros et al., 2017). However, new studies have been dedicated to integrating paleoseismological data in the calculation of seismic hazards and try to better characterize the continental seismic sources in Mexico (Rodríguez-Pérez et al., 2017; Zúñiga et al., 2017).

A discrete rupture of the entire VBF would result in a higher magnitude earthquake than the 1912 Acambay multi-segment rupture which generated major ground shaking (MM Intensity 7-8) in Mexico City, located $70 \mathrm{~km}$ from the epicenter (Suter et al., 1996; Suter, 2014). An earthquake along the VBF could be equally damaging, or even worse considering the exponential population growth during the last century.

It is important to consider that the VBF could rupture together with other faults located in the western Acambay Graben (multiple-segment rupture scenario). Indeed, the 1912 earthquake rupture extended along three fault systems of the eastern Acambay Graben (Acambay-Tixmadejé, intragraben and Pastores faults; Urbina and Camacho, 1913; Suter et al., 1996) and resulted in a $\mathrm{M}_{\mathrm{S}} 6.7$ earthquake. The possibility of such a major event is supported by the relative synchronicity between the last earthquakes recorded at the Guapa site (PE 1 and PE2; Fig. 9) and the more recent earthquakes recorded along the western central-graben fault systems (event 1; 4515 to 50 cal. yr BP; Ortuño et al., 2018). 
Another consideration is whether the Pastores fault and VBF could rupture in sequence. Suter et al. (1995), Langridge et al. (2013), and Ortuño et al. (2015) discussed the possibility that the VBF and Pastores fault, separated by a $<1 \mathrm{~km}$ wide step, could be connected at depth and could break at the same time during an earthquake. Such a scenario has recently been observed in Italy for normal events (2016 $\mathrm{M}_{\mathrm{W}} 6.5$ Norcia; Civico et al., 2017) and in New Zealand for strike-slip events (2016 $\mathrm{M}_{\mathrm{W}}$ 7.8 Kaikoura event) at a larger scale (Stirling et al., 2017). Recent studies about the empirical bounds on rupture propagation predict that steps of $1 \mathrm{~km}$ or greater will be effective in stopping a rupture about $37 \%$ of the time (Biasi and Wesnousky, 2016). Accordingly the rupture crosses such a step $63 \%$ of the time and it is therefore plausible that the VBF to the Pastores fault break together, accounting for a total length of $80 \mathrm{~km}$. Such a rupture would cause an earthquake of $\mathrm{M}_{\mathrm{W}} 7$ (Wesnousky, 2008). More studies at the junction between the two faults could confirm or invalidate the hypothesis of previous ruptures having jumped this step-over.

Finally, considering the megacity of Mexico City and medium sized cities like Queretaro, Morelia, Toluca, Celaya and San Juan del Rio, more than 30 million people live within a radius of $80 \mathrm{~km}$ of the Acambay Graben. Even though the likelihood of a large crustal earthquake is small compared to the occurrence of a subduction earthquake in Mexico, its consequences would be disastrous considering the lack of preparedness and the poor quality of the building infrastructure.

\section{Conclusions}

Five paleoseismic trenches along the westernmost part of the $48 \mathrm{~km}$ long Venta de Bravo Fault show evidence of Holocene and historical earthquake ruptures. Evidence for at least eight late Pleistocene to Holocene paleoearthquake ruptures, dated with 23 radiocarbon dates, was reported. The last six paleoseismic events are well bracketed within the Holocene since the first two other events (PE 6 and 7) occurred before 24,268 cal. yr BP. The average recurrence interval of faulting 
varies between 1940 (PE 1-PE 6) and 2390 years (PE 1-PE 5). The Holocene slip rate along the western segment of the fault is $0.22-0.24 \mathrm{~mm} \mathrm{yr}^{-1}$. On the basis of a range of single-event displacements from 18 to $100 \mathrm{~cm}$, an average displacement of ca. $45 \mathrm{~cm}$, a subsurface rupture length of $26 \mathrm{~km}$ (western segment) and $48 \mathrm{~km}$ (entire fault), and a $\mathrm{M}_{\mathrm{W}} 6.3$ to 6.9 is estimated for discrete rupture events on the VBF. Compared to the seismic parameters previously estimated for the faults in the Acambay Graben, these results point to the VBF as the major seismic source of the Acambay Graben in terms of length, slip rate and recurrence interval of faulting. Moreover, the synchronicity between the last paleoearthquakes recorded along the VBF and the western centralgraben fault systems indicates that the VBF could rupture together with other faults of the Acambay Graben. In this case, the associated earthquake could reach a magnitude greater than 7.

Though large magnitude earthquakes on the VBF are infrequent compared to the subduction events along the Mexican Pacific coast, their occurrence needs to be integrated into calculations of seismic hazard for central Mexico. Much of the population of Mexico lives within this region and is at risk of being exposed to strong ground shaking (MM Intensity 7-8), particularly taking into account the site effect in the shallow lake basins where the largest population centers are located.

\section{Acknowledgments}

This work was supported by the Universidad Nacional Autónoma de México [PAPIIT grant IA101615 and IA102317] and the Consejo Nacional de Ciencias y Tecnología [CONACyT grant CB 2009-01/129010]. Radiocarbon dates were obtained thanks to IRD and IRSN support to UMS 2572 LMC14 (CEA-CNRS-IRD-IRSN-MCC), Saclay (France). The mapping of the volcanic units was obtained through the PAPIIT grant IN104615. We are thankful to Max Suter, an anonymous reviewer and the guest-editor of the Special Issue Catherine Chagué for their detailed and constructive comments of the manuscript and to Tom Wheaton for improving the English text. We 
thank Pilar Villamor, Ivan Sunyé-Puchol, Ona Coromitas, Petra Štěpančíková, Rodrigo Alejandro León Loya, Janette Merlo Chávez, Moritz Kritz, María Helbig, Ernesto López and Daniele Dell'Erba for field assistance and the owners of the paleoseismological sites, Joel Pérez López (Guapamacataro) and Jaime López (Campo Hermoso) for their permissions.

\section{References}

Astiz-Delgado, L.M., 1980. Sismicidad en Acambay, Estado de México-el temblor del 22 de febrero de 1979. M.Sc. thesis, Facultad de Ingeniería, Universidad Nacional Autónoma de México, Mexico.

Audemard, F.A., 2005. Paleoseismology in Venezuela: objectives, methods, applications, limitations and perspectives. Tectonophysics 408, 29-61.

Audemard, F.A., Michetti, A.M., 2011. Geological criteria for evaluating seismicity revisited: Forty years of paleoseismic investigations and the natural record of past earthquakes. In: Audemard, F.A., Michetti, A.M., McCalpin, J.P. (Eds.), Geological Criteria for Evaluating Seismicity Revisited: Forty Years of Paleoseismic Investigations and the Natural Record of Past Earthquakes. Geological Society of America Special Paper 479, 1-21.

Bayona Viveros, J.A., Suárez Reynoso, G., Ordaz Schroeder, M.G., 2017. A probabilistic seismic hazard assessment of the Trans-Mexican Volcanic Belt, Mexico based on historical and instrumentally recorded seismicity. Geofísica Internacional 56, 87-101. 
Benavente, C., Zerathe, S., Audin, L., Hall, S.R., Robert, X., Delgado, F., Carcaillet, J., ASTER

Team, 2017. Active transpressional tectonics in the Andean forearc of southern Peru quantified by

${ }^{10} \mathrm{Be}$ surface exposure dating of an active fault scarp. Tectonics 36, doi: 10.1002/2017TC004523.

Biasi, G.P., Wesnousky, S.G., 2016. Steps and gaps in ground ruptures: Empirical bounds on rupture propagation. Bulletin of Seismological Society of America 106, 1110-1124.

Bronk Ramsey, C., 2009. Bayesian analysis of radiocarbon dates. Radiocarbon 51, 337-360.

Campillo, M., Gariel, J.C., Aki K., Sánchez-Sesma, F.J., 1989. Destructive strong ground motion in Mexico city: Source, path, and site effects during great 1985 Michoacán earthquake. Bulletin of Seismological Society of America 79, 1718-1735.

Civico, R., Sapia, V., Di Giulio, G., Villani, F., Pucci, S., Baccheschi, P., Amoroso, S., Cantore, L., Di Naccio, D., Hailemikael, S., Smedile, A., Vassallo, M., Marchetti, M., Pantosti, D., 2017. Geometry and evolution of a fault-controlled Quaternary basin by means of TDEM and single-station ambient vibration surveys: The example of the 2009 L'Aquila earthquake area, central Italy. Journal Geophysical Research Solid Earth 122, 2236-2259.

Ferrari, L., Orozco-Esquivel, T., Manea, V., Manea, M., 2012. The dynamic history of the TransMexican Volcanic Belt and the Mexico subduction zone. Tectonophysics 522-523, 122-149.

García Acosta, V., Suárez Reynoso, G., 1996. Los Sismos en la Historia de México, Tomo I: Universidad Nacional Autónoma de México/Centro de Investigaciones y Estudios Superiores en Antropología Social/Fondo de Cultura Económica, Mexico. 
Giardini, D., Grünthal, G., Shedlock, K.M., Zhang, P., 2003. The GSHAP Global Seismic Hazard Map. In: Lee, W., Kanamori, H., Jennings, P., Kisslinger, C. (Eds.), International Handbook of Earthquake \& Engineering Seismology. International Geophysics Series 81 B, Academic Press, Amsterdam, pp. 1233-1239.

Lacan, P., Nivière, B., Rousset, D., Sénéchal P., 2012. Late Pleistocene folding above the Mail Arrouy Thrust, North-Western Pyrenees (France). Tectonophysics 541-543, 57-68.

Lacan, P., Zúñiga, R., Ortuño, M., Persaud, M., Aguirre, G., Langridge, R., Villamor, P., Perea, H., Štěpančíková, P., Carreon, D., Cerca, M., Suñe Puchol, I., Corominas, O., Audin, L., Baize, S., Lawton, T., Rendón, A., 2013. Paleoseismological history of the Acambay Graben (Central Mexico). AGU Fall Meeting. American Geophysical Union, San Francisco, USA, 94(49), Abstract T23C-2591.

Langridge, R.M., Weldon, R.J., Moya, J.C., Suárez, G., 2000. Paleoseismology of the 1912 Acambay earthquake and the Acambay-Tixmadejé fault, Trans-Mexican Volcanic Belt. Journal of Geophysical Research 105, 3019-3037.

Langridge, R.M., Persaud, M., Zúñiga, F.R., Aguirre-Díaz, G.J., Villamor, P., Lacan, P., 2013. Preliminary paleoseismic results from the Pastores fault and its role in the seismic hazard of the Acambay graben, Trans-Mexican Volcanic Belt, Mexico. Revista Mexicana de Ciencias Geológicas 30, 463-481.

Martínez Reyes, J., Nieto-Samaniego, A.F., 1990. Efectos geológicos de la tectónica reciente en la parte central de México. Revista del Instituto de Geología de la Universidad Nacional Autónoma de México 9, 33-50. 
McCalpin, J.P., 2009. Paleoseismology (second edition). Academic Press-Elsevier, Amsterdam.

Meghraoui, M., Delouis, B., Ferry, M., Giardini, D., Huggenberger, P., Spottke, I., Granet, M., 2001. Active normal faulting in the Upper Rhine Graben and paleoseismic identification of the 1356 Basel earthquake. Science 80, 2070-2073.

Messager, G., Nivière, B., Martinod, J., Lacan, P., Xavier, J.P., 2010. Geomorphic evidence for PlioQuaternary compression in the Andean foothills of the southern Neuquén Basin, Argentina. Tectonics 29, TC4003, doi: 10.1029/2009TC002609.

Mooser, F., 1972. The Mexican volcanic belt: Structure and tectonics. Geofísica Internacional 12, $55-70$

Nivière, B., Lacan, P., Regard, V., Delmas, M., Calvet, M., Huyghe, D., Roddaz, B., 2016.

Evolution of the Late Pleistocene Aspe River (Western Pyrenees, France). Signature of climatic events and active tectonics. Comptes Rendus Geociences 348, 203-212.

Orozco y Berra, J.D., 1887. Efemérides séismicas Mexicanas. Memorias de la Sociedad Científica Antonio Alzate 1, 303-541.

Ortuño, M., Masana, E., García-Meléndez, E., Martínez-Díaz, J., Štěpančíková, P., Cunha, P.P., Sohbati, R., Canora, C., Buylaert, J.P., Murray, A.S., 2012. An exceptionally long paleoseismic record of a slow-moving fault: The Alhama de Murcia fault (Eastern Betic shearzone, Spain). Geological Society of America Bulletin 124, 1474-1494. 
Ortuño, M., Zúñiga, F.R., Aguirre-Díaz, G.J., Carreón-Freyre, D., Cerca, M., Roverato, M., 2015. Holocene paleo-earthquakes recorded at the transfer zone of two major faults: the Pastores and Venta de Bravo faults (Trans-Mexican Volcanic Belt). Geosphere 11, 160-184.

Ortuño, M., Coromitas, O., Zúñiga, F.R., Lacan, P., Perea, H., Aguirre-Díaz, G., Štěpančíková, P., Villamor, P., Ramirez-Herrera, T., 2018. Evidence of recent ruptures in the central faults of the Acambay Graben (Central Mexico). Sedimentary Geology.

Perea, H., 2009. The Catalan seismic crisis (1427 and 1428; NE Iberian Peninsula): Geological sources and earthquake triggering. Journal of Geodynamics 47, 259-270.

Perea, H., Masana, E., Santanach, P., 2012. An active zone characterized by slow normal faults, the northwestern margin of the València trough (NE Iberia): a review. Journal of Iberian Geology 38, $31-52$.

Rodríguez-Pascua, M.A., Pérez-López, R., Garduño-Monroy, V.H., Perucha, M.A., 2017. Estimation of the epicentral area of the 1912 Acambay earthquake (M 6.9, Mexico) determined from the earthquake archaeological effects (EAE) and the ESI07 macroseismic scale. Quaternary International 451, 74-86.

Rodríguez-Pérez, Q., Zúñiga, F.R., 2017. Seismicity characterization of the Maravatío-Acambay and Actopan regions, Central Mexico. Journal of South American Earth Sciences 76, 264-275.

Rodríguez-Pérez, Q., Zúñiga, F.R., Lacan, P., 2017. Paleoseismological uncertainty estimation in the Acambay region, Central Mexico. Geofísica Internacional 56, 255-268. 
Shedlock, K.M., Giardini, D., Grünthal G., Zhang, P., 2000. The GSHAP global seismic hazard map. Seismological Research Letters 71, 679-686.

Stirling, M., Rhoades, D., Berryman, K., 2002. Comparison of earthquake scaling relations derived from data of the instrumental and preinstrumental era. Seismological Society of America Bulletin $92,812-830$.

Stirling, M., Goded, T., Berryman, K., Litchfield, N., 2013. Selection of earthquake scaling relationships for seismic-hazard analysis. Seismological Society of America Bulletin 103, 29933011.

Stirling, M., Litchfield, N.J., Villamor, P., Van Dissen, R.J., Nicol, A., Pettinga, J.R., Barnes, P.M., Langridge, R., Little, T., Barrell, D.J.A., Mountjoy, J.J., Ries, W.F., Rowland, J., Fenton, C., Hamling, I.J., Asher, C., Barrier, A., Benson, A., Bischoff, A., Borella, J., Carne, R., Cochran, U.A., Cockroft, M., Cox, S.C., Duke, G., Fenton, F., Gasston, C., Grimshaw, C., Hale, D., Hall, B., Hao, K.X., Hatem, A., Hemphill-Haley, M., Heron, D.W., Howarth, J., Juniper, Z., Kane, T., Kearse, J., Khajavi, N., Lamarche, G., Lawson, S., Lukovic, B., Madugo, C., Manousakis, I., McColl, S., Noble, D., Pedley, K., Sauer, K., Stah, T., Strong, D.T., Townsend, D.B., Toy, V., Villeneuve, M., Wandres, A., Williams, J., Woelz, S., Zinke, R., 2017. The $\mathrm{M}_{\mathrm{W}} 7.82016$ Kaikōura earthquake: Surface fault rupture and seismic hazard context. Bulletin of the New Zealand Society for Earthquake Engineering 50, 73-84.

Suárez, G., Caballero-Jiménez, G.V., 2012. Quantitative evaluation of historical earthquakes on the Mexican Volcanic Belt. $3^{\text {rd }}$ INQUA-IGPC-567, International Workshop on Active Tectonics, Paleoseismology and Archaeoseismology, Morelia, Mexico, pp. 183-186. 
Sunyé-Puchol, I., Lacan, P., Ortuño, M., Villamor, P., Audin, L., Zúñiga, F.R., Langridge, R.M., Aguirre-Díaz, G.J., Lawton, T.F., 2015. La falla San Mateo: Nuevas evidencias paleosismológicas de fallamiento activo en el graben de Acambay, México. Revista Mexicana de Ciencias Geológicas $32,361-375$.

Suter, M., 2014. Comment on "Estimation of ground motion in Mexico City from a repeat of the M $\sim$ 7:0 Acambay earthquake of 1912" by Shri Krishna Singh, Arturo Iglesias, Mario Ordaz, Xyoli Pérez-Campos, and Luis Quintanar. Bulletin of the Geological Society of America 104, 2562-2564.

Suter, M., 2015. The $1567 \mathrm{M}_{\mathrm{W}} 7.2$ Ameca, Jalisco earthquake (western Trans-Mexican Volcanic Belt): Surface rupture parameters, seismogeological effects, and macroseismic intensities from historical sources. Seismological Society of America Bulletin 105, 646-656.

Suter, M., Quintero, O., Johnson, C.A., 1992. Active faults and state of stress in the central part of the Trans-Mexican Volcanic Belt, Mexico. The Venta de Bravo fault. Journal of Geophysical Research 97, 11983-11993.

Suter, M., Quintero, O., López, M., Aguirre-Díaz, G.J., Ferrar, E., 1995. The Acambay graben: Active intraarc extension in the Trans-Mexican Volcanic Belt. Tectonics 14, 1245-1262.

Suter, M., Carrillo-Martínez, M., Quintero-Legorreta, O., 1996. Macroseismic study of earthquakes in the central and eastern parts of the Trans-Mexican Volcanic Belt. Seismological Society of America Bulletin 86, 1952-1963.

Suter, M., López-Martínez, M., Quintero-Legorreta, O., Carrillo-Martínez, M., 2001. Quaternary intraarc extension in the central Trans-Mexican volcanic belt. Geological Society of America 
Bulletin 113, 693-703.

Tena-Colunga, A., Mena-Hernández, U., Pérez-Rocha, L.E., Avilés, J., Ordaz, M., Vilar, J.I., 2009.

Updated seismic design guidelines for model building code of Mexico. Earthquake Spectra 25, 869898.

Urbina, F., Camacho, H., 1913. La zona megaseísmica Acambay-Tixmadejé, Estado de México, conmovida el 19 de noviembre de 1912. Boletín del Instituto Geológico de México 32, 1-125.

Wells, D.L., Coppersmith, K.J., 1994. New empirical relationships among magnitude, rupture length, rupture width, rupture area, and surface displacement. Seismological Society of America Bulletin 84, 974-1002.

Wesnousky, S.G., 2008. Displacement and geometrical characteristics of earthquake surface ruptures: Issues and implications for seismic hazard analysis and the process of earthquake rupture. Seismological Society of America Bulletin 98, 1609-1632.

Zúñiga, F.R., Suárez, G., Figueroa-Soto, A., Mendoza, A., 2017. A first order seismotectonic regionalization of Mexico for seismic hazard and risk estimation. Journal of Seismology https://doi.org/10.1007/s10950-017-9666-0.

\section{Figure captions:}


Figure 1. Map of the Acambay Graben showing active faults and major volcanic complexes, including Altamirano, Amealco caldera, Puruagua range and San Miguel. Red circles represent epicenter located by the National Seismological Service of Mexico (SSN). The 1912, $\mathrm{M}_{\mathrm{S}} 6.7$ Acambay earthquake is shown by a red star. Blue star and circles represent the $1979, \mathrm{M}_{\mathrm{W}} 5.3$ Maravatío main shock and aftershock sequence (Rodríguez-Pérez and Zúñiga, 2017). Stress orientations of the studied area, resulting from inversion of fault plane striations, come from Suter et al. (1995). White box shows the location of Fig. 3. 30-m-resolution digital elevation model derived from Geomapapp. Modified from Lacan et al. (2013).

Figure 2. Simplified geologic map of the Acambay Graben showing the main lithostratigraphic units and the fault traces identified within the graben (modified from Ortuño et al., 2015). VBF: Venta de Bravo Fault, 1, 2 and 3: Eastern Segment (purple); 4: Central Segment (Orange); 5, 6, 7 and 8: Western Segment (red). Paleoseismological trench sites from other studies are also reported. Shaded relief derived from the 30-m-resolution digital elevation model by Instituto Nacional de Estadística y Geografía de México (INEGI, 2011) is used as a background. Plio: Pliocene; Qt: Quaternary.

Figure 3. To the left: $30 \mathrm{~m}$ resolution Digital Elevation Model (DEM) of the three segments of the Venta de Bravo Fault (derived from GeomapApp). Right: Topographic profile across the Venta de Bravo fault scarp (Altitude in meters, distance in kilometers, vertical exaggeration $\mathrm{x} 3$ ). The location of the profiles is indicated on the DEM. VBF: Venta de Bravo Fault, 1, 2 and 3: Eastern Segment (purple); 4: Central Segment (Orange); 5, 6, 7 and 8: Western Segment (red); PF: Pastores fault. The white rectangle indicates the location of Fig. 4A.

Figure 4. (A) Aerial orthophoto of the western tip of the Western Venta de Bravo Fault segment. The traces of the main faults are highlighted in white, and the location of the three 
paleoseismological sites, Hermoso (B), Guapa (C), and Terreros (D), is indicated by white rectangles. The Cachiví River (in blue) crosses the area from south to north. In B, C and D, small rectangles localized the trenches excavated and presented (red) or discard (orange) in this work. Orthophoto from Mexican National Institute of Statistics and Geography (INEGI).

Figure 5. Photographs of the paleoseismological sites and trench exposures. (A and B) View of the Terreros 1 trench. (C and D) View of the Guapa 3 trench. (E) View of the Hermoso 2 trench. The fault scarp is highlighted in red.

Figure 6. Logs of the Terreros 1 trench. See text and table 2 for description of units. The western wall of the trench is flipped for ease of comparison.

Figure 7. Logs of the Guapa 2 and Guapa 3 trenches. See text and table 2 for description of units. Western walls of the two trenches are flipped for ease of comparison. Photomosaics are in supplementary material.

Figure 8. Logs of the Hermoso 1 and Hermoso 2 trenches. See text and Table 2 for description of units.

Figure 9. Timing based on radiocarbon ages of the paleoearthquakes identified at the Terreros, Guapa and Hermoso sites on the Western Venta de Bravo Fault segment. The right column shows the related displacements during each paleoearthquakes. 


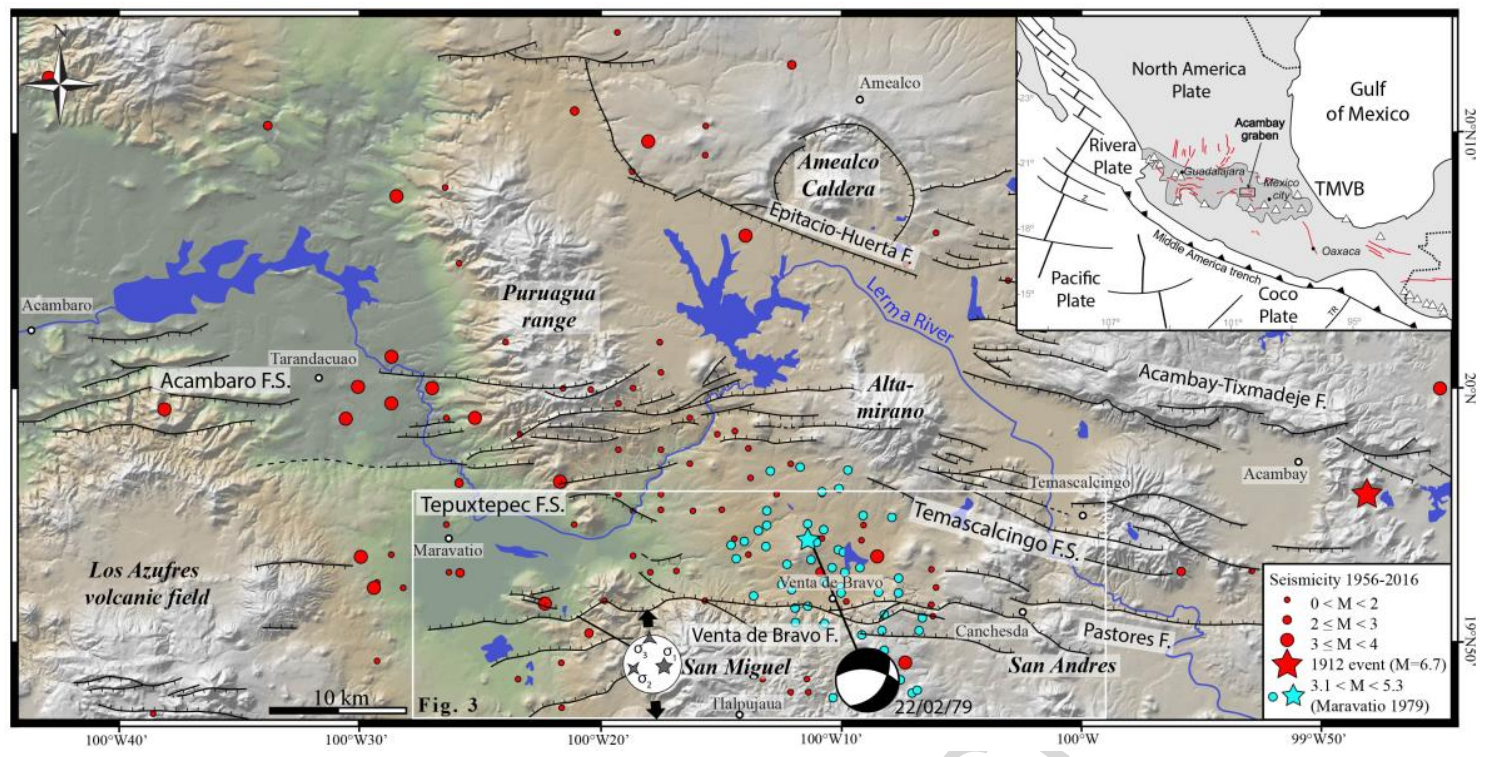

Figure 1 


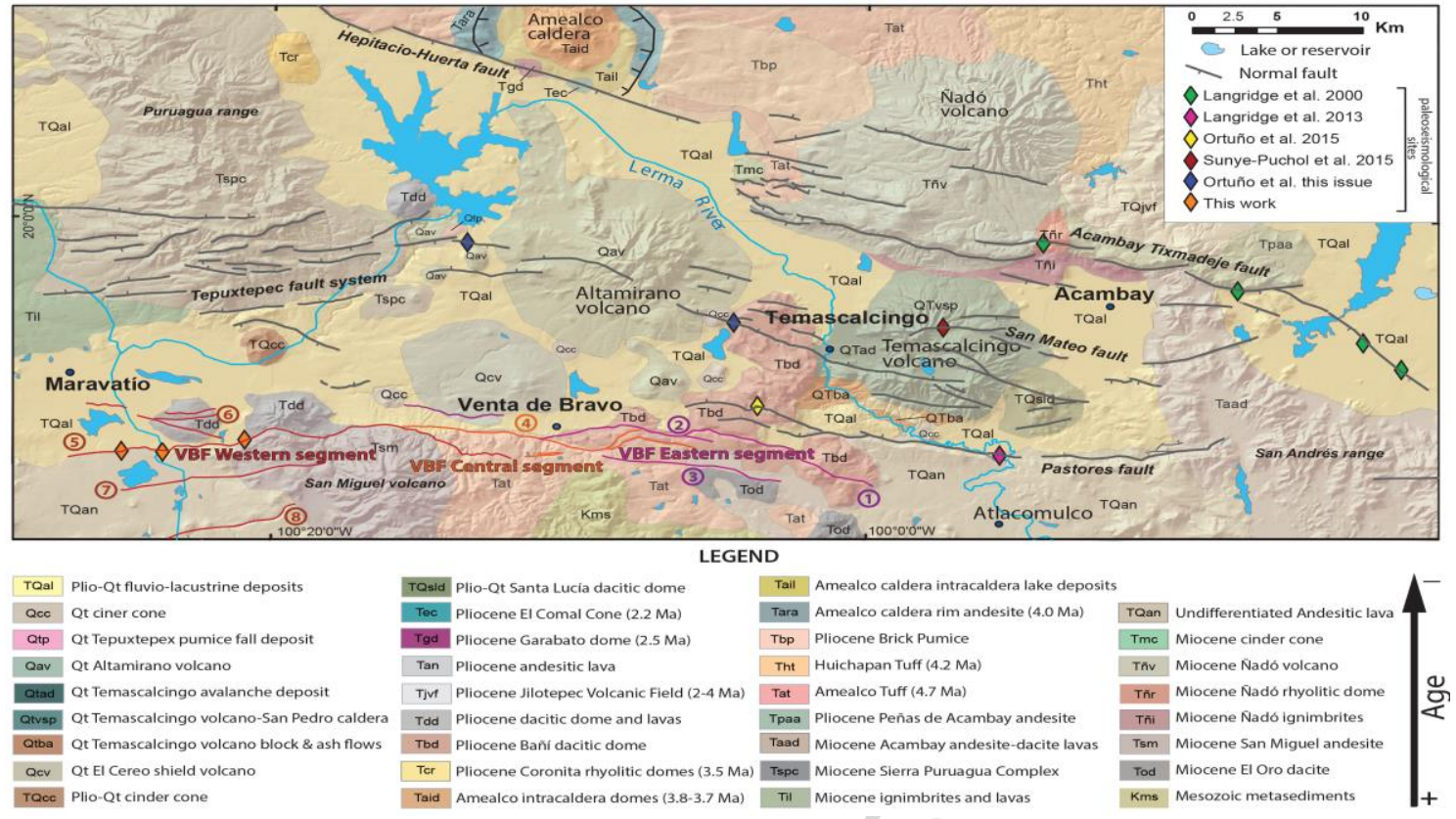

Figure 2 

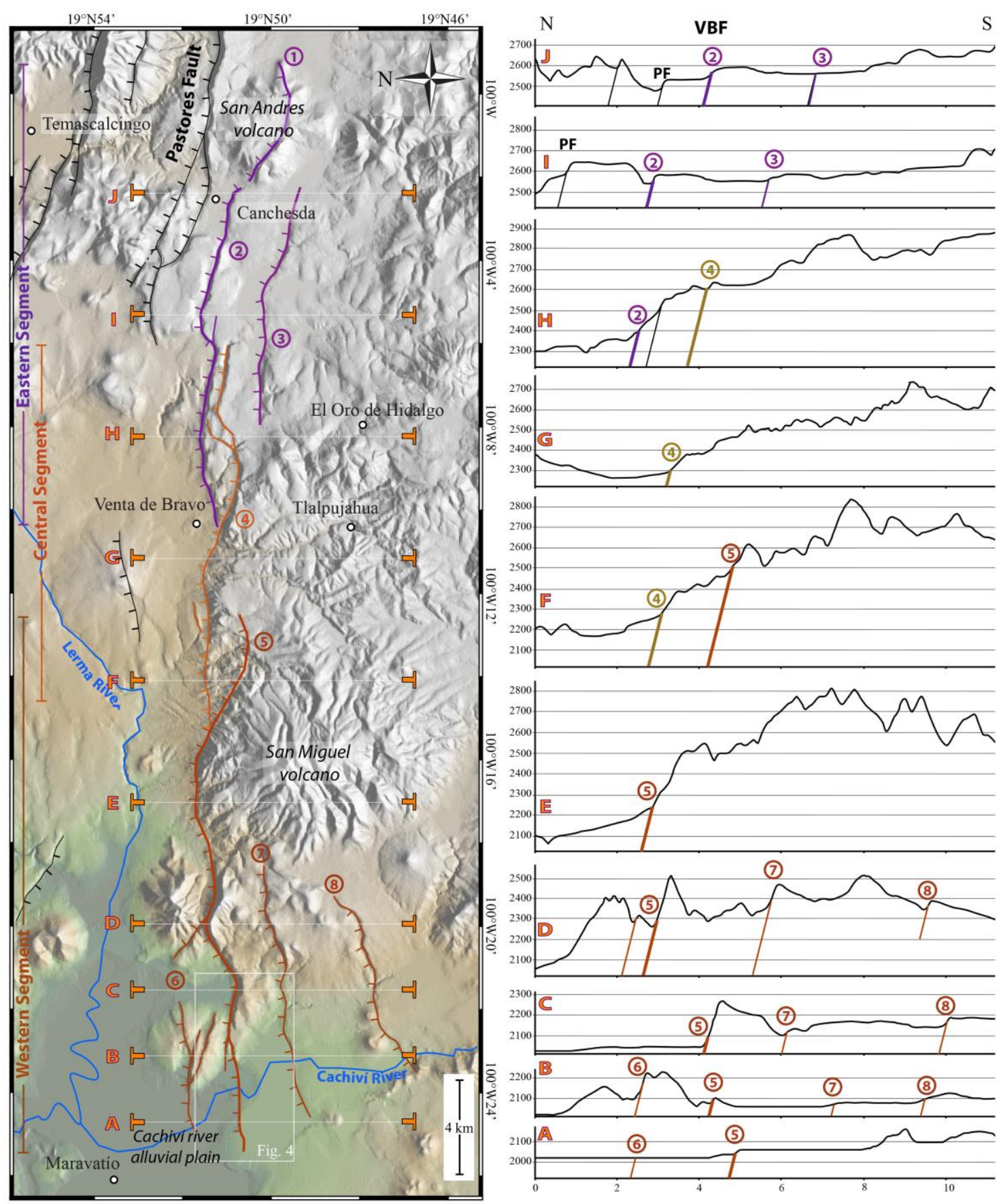

Figure 3 

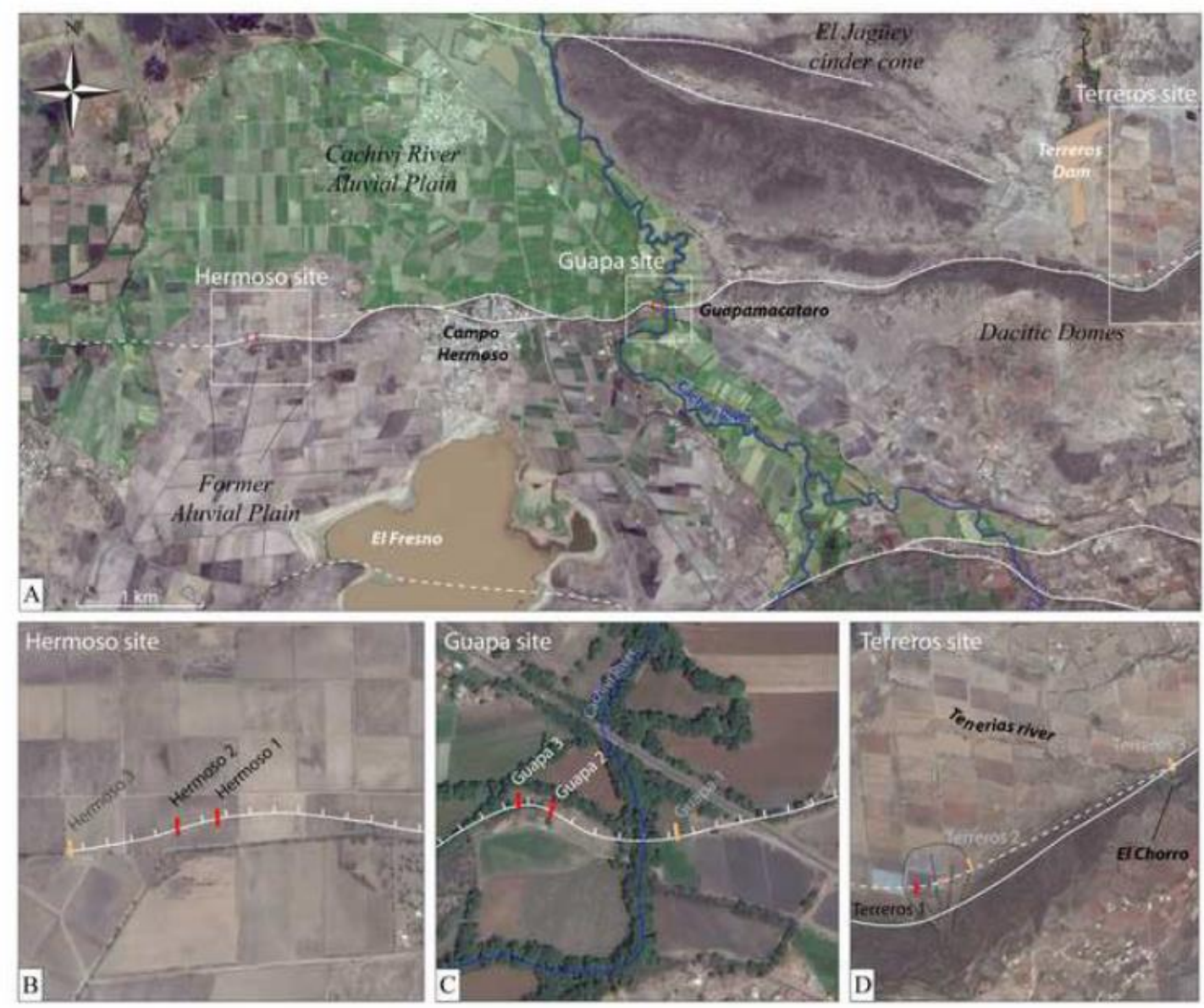

Figure 4

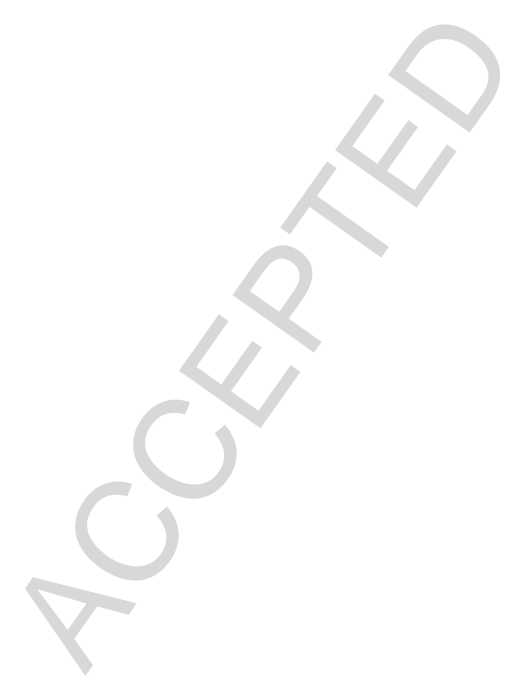




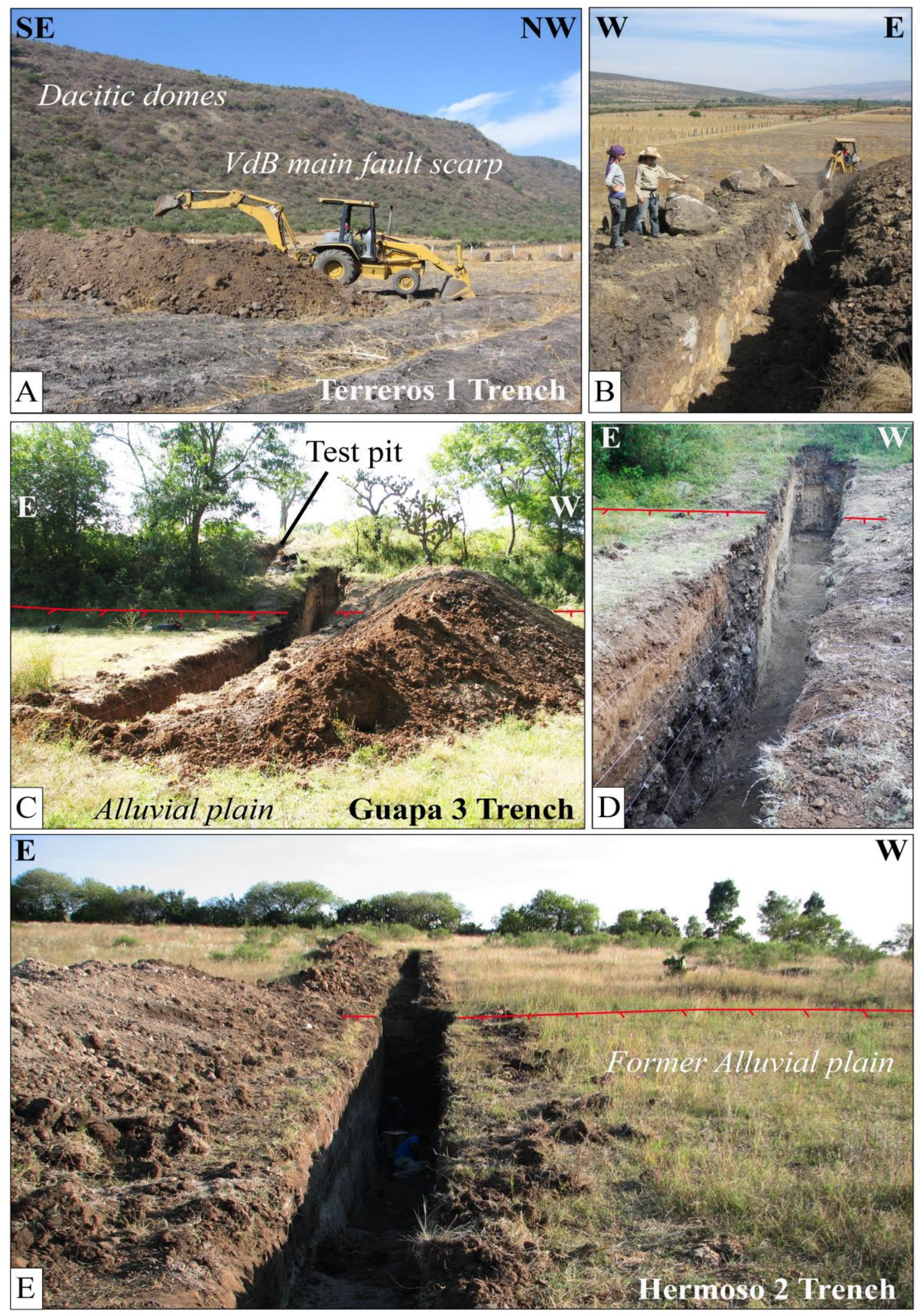

Figure 5 


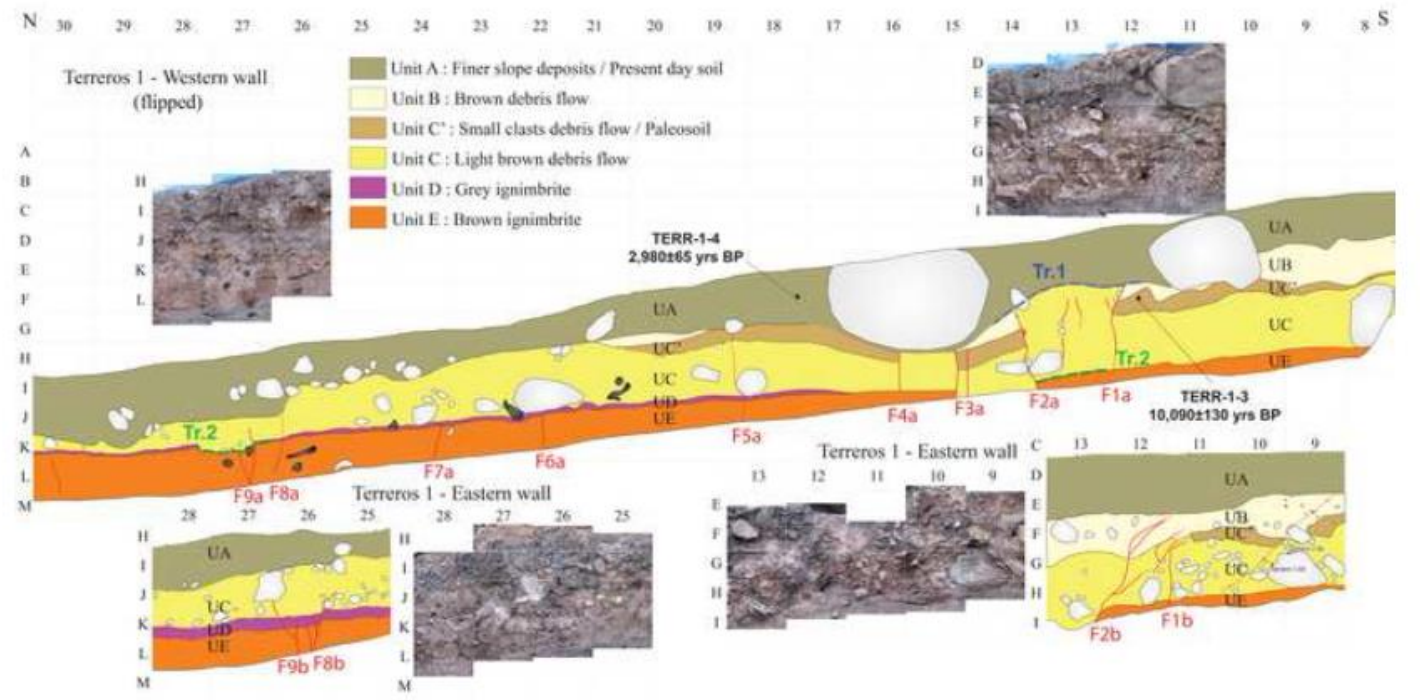

Figure 6 


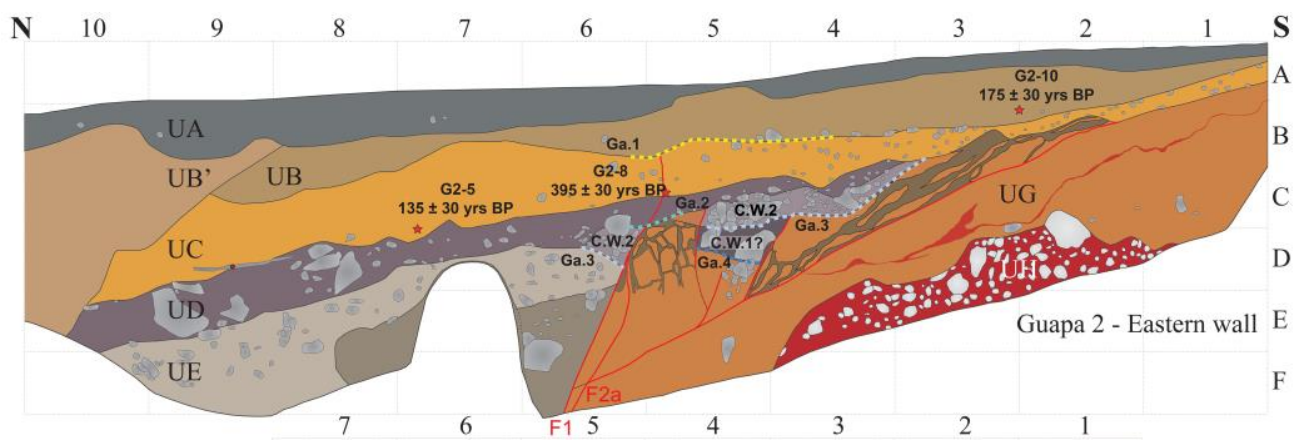

Unit A : Present day soil

Unit B : Pale brown paleosoil

Unit C : Dark brown paleosoil

Unit D : colluvium deposit

Unit E : Ash rich paleosoil

Unit F : Epiclastic volcanic deposits

Unit G : Ignimbrite (possibly reworked)

80 Unit $\mathrm{H}$ : Andesitic lava flow

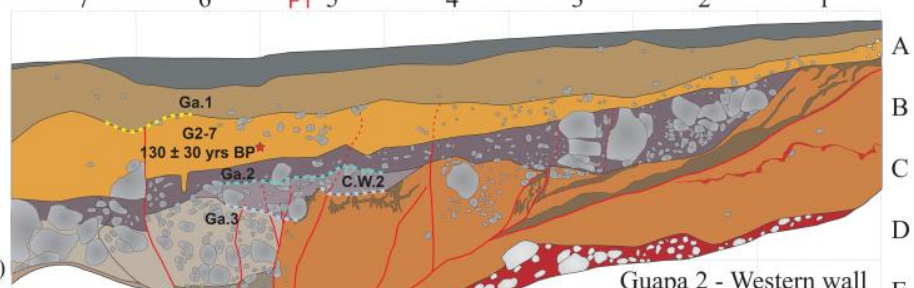

F4a $.0 .3^{\circ}$ (flipped)

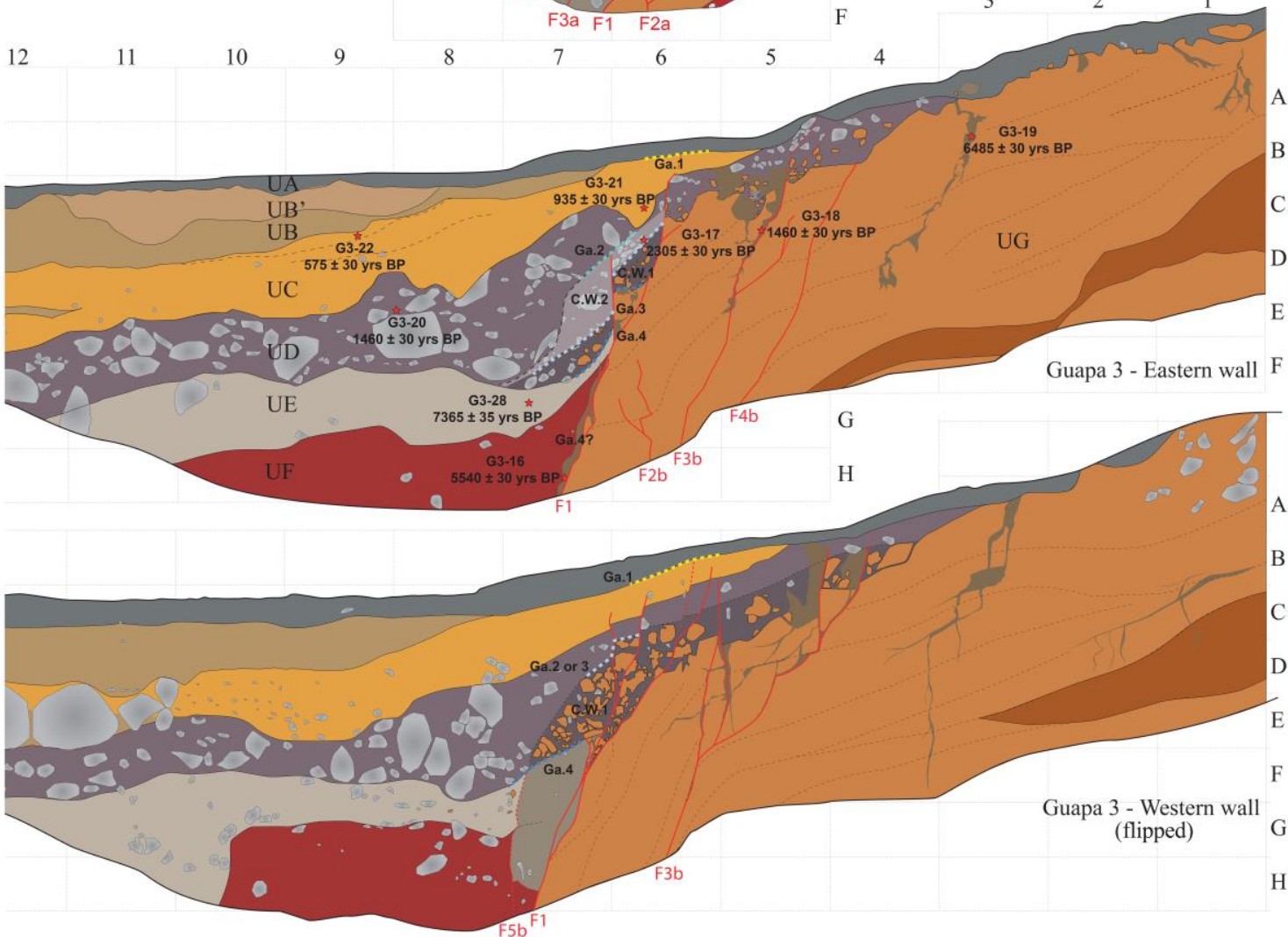

Figure 7 

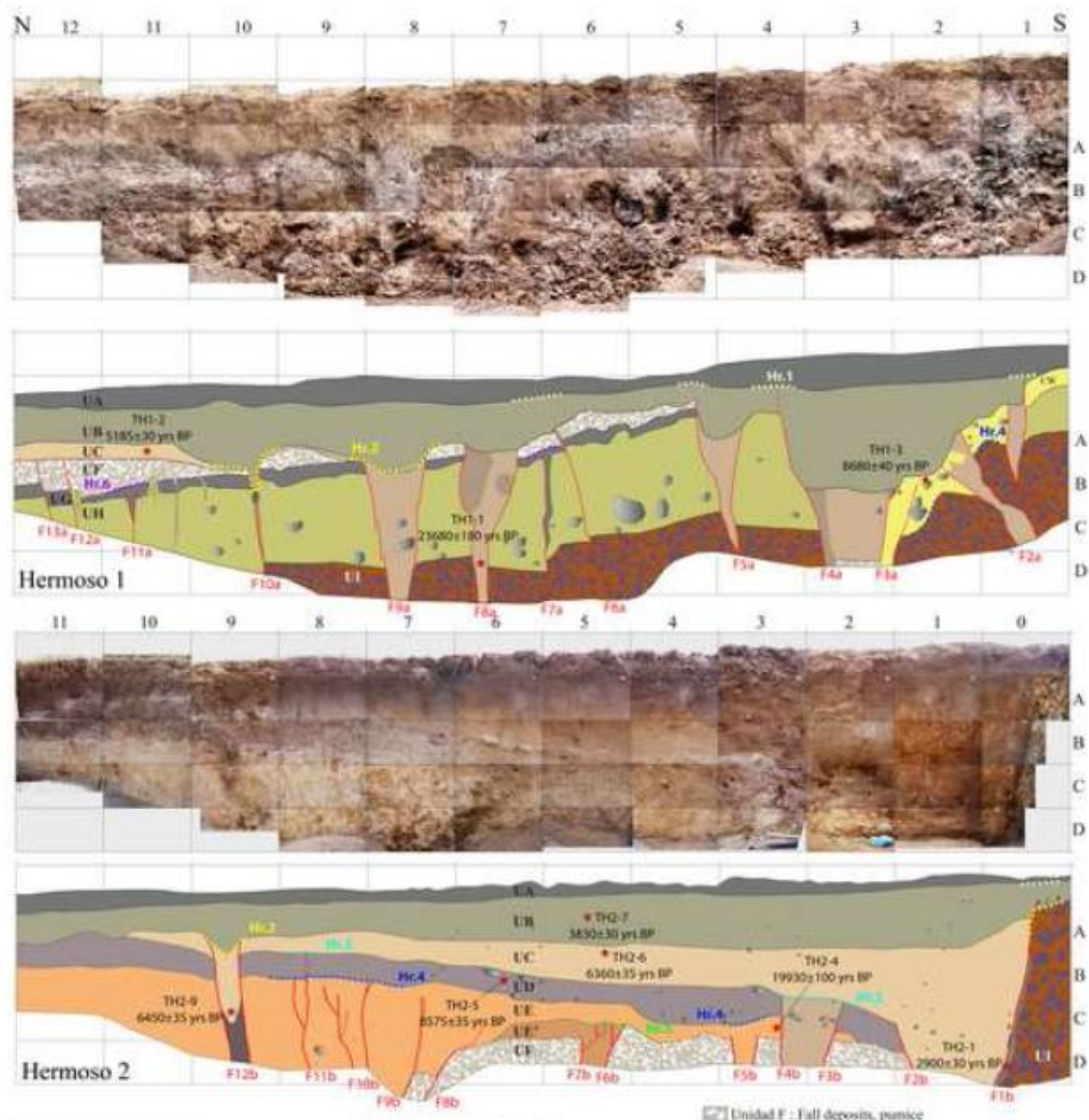

EVibat A : Proment dy will

Unisbat D: Debre flirw deposit

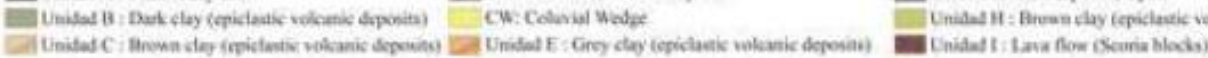

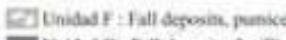

Figure 8

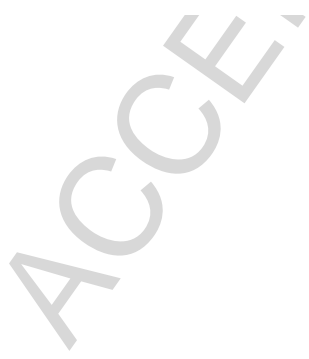




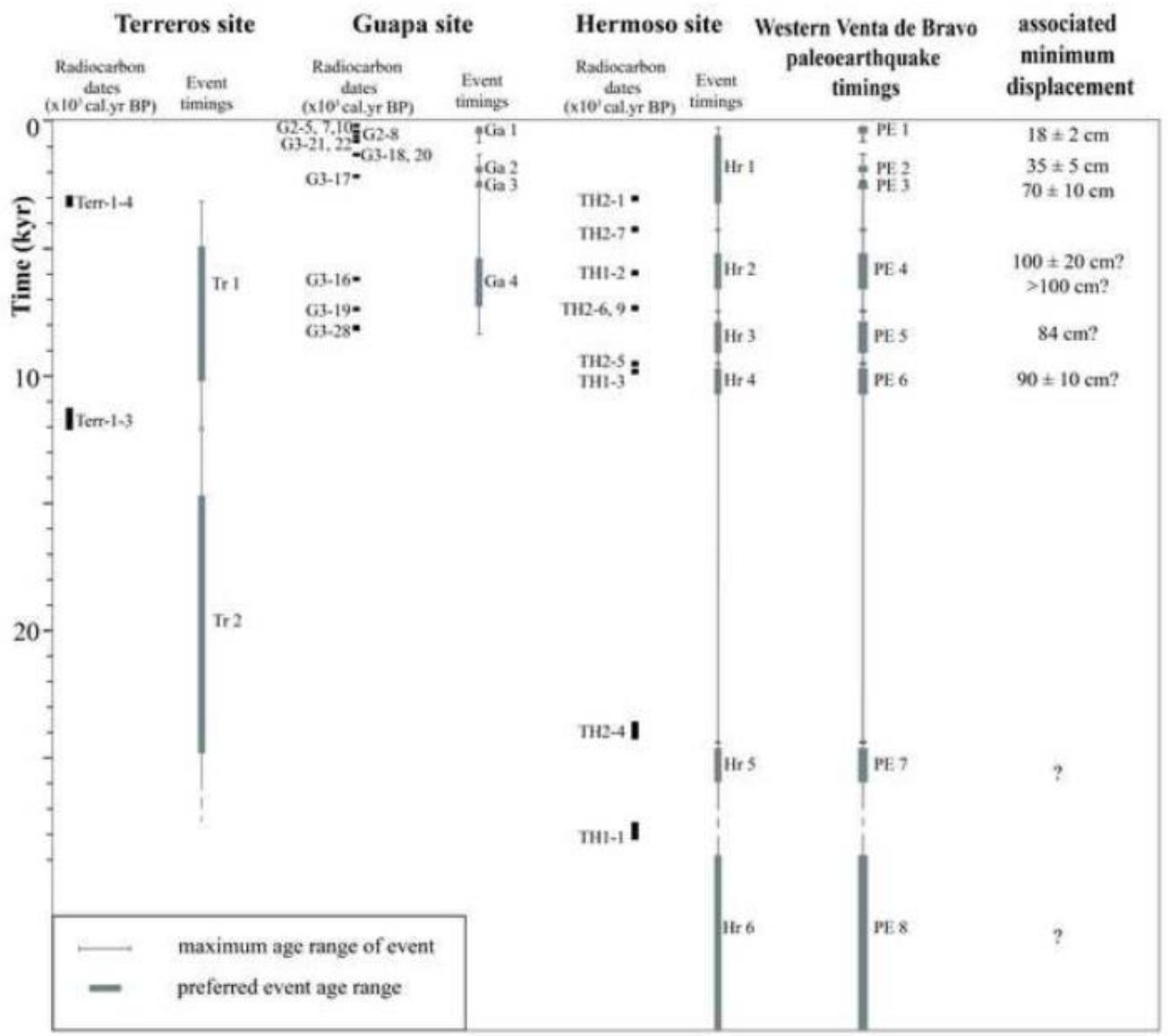

Figure 9 
Table 1. Dating results. Arizona univ., Arizona University Radiocarbon Laboratory for conventional dating, and IRD-LMC14 and CEA Saclay for AMS dating. The calibrated ages have been obtained using OxCal 4.2 software (Bronk Ramsey, 2008), $2 \sigma$ uncertainty. All ages are rounded to the nearest multiple of 5.

\begin{tabular}{cccc}
$\begin{array}{c}\text { Sample name } \\
\text { (unit) }\end{array}$ & Type of sample & $\begin{array}{c}\text { Radiocarbon Age } \\
\text { (years BP) }\end{array}$ & $\begin{array}{c}\text { Calibrated Age } \\
\text { (years cal. BP) }\end{array}$ \\
\hline
\end{tabular}

\section{Terreros trench}

Terr-1-3 (UC)

Terr-1-4 (UA)
Charcoal

Charcoal

$$
\begin{gathered}
10090 \pm 130 \\
2980 \pm 65
\end{gathered}
$$

$12128-11242$

3346-2966

\section{Guapa trenches}

$$
\begin{gathered}
\text { G2-5 (UC) } \\
\text { G2-7 (UC) } \\
\text { G2-8 (UC) } \\
\text { G2-10 (UB) } \\
\text { G3-16 (R) } \\
\text { G3-17 (CW2) } \\
\text { G3-18 (R) } \\
\text { G3-19 (R) } \\
\text { G3-20 (UD) } \\
\text { G3-21 (UC) } \\
\text { G3-22 (UC) } \\
\text { G3-28 (UE) }
\end{gathered}
$$

\section{Hermoso trenches}

TH2-1 (R)
TH2-4 (UE)
TH2-5 (UD)
TH2-6 (UC)
TH2-7 (UB)
TH2-9 (R-UC?)
TH1-1 (R)
TH1-2 (UC)
TH1-3 (CW)

Soil (Bulk)

Soil (Bulk)

$19930 \pm 100$

Soil (Bulk)

Soil (Bulk)

Soil (Bulk)

Soil (Bulk)

Soil (Bulk)

Soil (Bulk)

Soil (Bulk)
$2900 \pm 30$

3157-2954

$\begin{array}{cc}135 \pm 30 & 279-7 \\ 130 \pm 30 & 275-8 \\ 395 \pm 30 & 511-322 \\ 175 \pm 30 & 294-34 \\ 5540 \pm 30 & 6400-6291 \\ 2305 \pm 30 & 2359-2185 \\ 1460 \pm 30 & 1397-1302 \\ 6485 \pm 30 & 7458-7322 \\ 1460 \pm 30 & 1397-1302 \\ 935 \pm 30 & 924-788 \\ 575 \pm 30 & 648-530 \\ 7365 \pm 35 & 8315-8046\end{array}$

$8575 \pm 35$

24268-23691

9597-9491

7419-7180

4406-4102

7431-7294

28140-27485

5992-5909

9737-9543 
Table 2. Sedimentary description and genetic interpretation of units exposed in the

trench walls of Terreros, Guapa and Hermoso sites.

\begin{tabular}{|c|c|c|}
\hline Sites & Sedimentological description & Interpretation \\
\hline \multicolumn{3}{|c|}{ Terreros } \\
\hline Unit A & $\begin{array}{l}\text { Up to } 1.3 \mathrm{~m} \text { thick black silt, sand and organic material. Ploughing } \\
\text { disturbs the first } 30 \mathrm{~cm} \text {. }\end{array}$ & $\begin{array}{l}\text { Present day slope deposits } \\
\text { and top soil (ploughed) }\end{array}$ \\
\hline Unit $B$ & $\begin{array}{l}60-80 \mathrm{~cm} \text { thick heterometric and matrix-supported conglomerate with } \\
\text { angular clasts without internal grading }\end{array}$ & Brown debris flow \\
\hline Unit $C^{\prime}$ & $\begin{array}{l}30 \mathrm{~cm} \text { thick small clasts }(<15-20 \mathrm{~cm}) \text { dispersed deposit in sandy } \\
\text { matrix. Brown dark carbon-rich clay at the top. }\end{array}$ & $\begin{array}{l}\text { Small clasts debris flow / } \\
\text { Paleosol }\end{array}$ \\
\hline Unit $C$ & $\begin{array}{l}\text { Up to } 1 \mathrm{~m} \text { thick heterometric and matrix-supported conglomerate of } \\
\text { angular clasts without internal grading in sandy and silty light brown } \\
\text { matrix. Angular and subangular boulders (centimetrics to } 1.3 \mathrm{~m} \text { ). The } \\
\text { clasts are derived from Las Américas ignimbrites, a deposit of the } \\
\text { Amealco volcano made of pink to grey andesite with black vitrophyre. }\end{array}$ & Light brown debris flow \\
\hline Unit D & $\begin{array}{l}20 \mathrm{~cm} \text { thick grey ash-supported clasts of andesite }(<10 \mathrm{~cm} \text { diameter }) \text {. } \\
\text { It contains } 20 \% \text { of crystals of quartz, sanidine and hornblende. }\end{array}$ & $\begin{array}{l}\text { Grey ignimbrite (Upper part } \\
\text { of Unit E?) }\end{array}$ \\
\hline Unit E & $\begin{array}{l}\text { Up to } 1 \mathrm{~m} \text { brown ash-supported dispersed clasts of andesite }(<15 \mathrm{~cm} \\
\text { diameter) and glass "nodules" with concentric fractures (probably } \\
\text { obsidian) embedded in a sandy-clayey matrix. It contains } 20 \% \text { of } \\
\text { crystals of quartz, sanidine and hornblende. }\end{array}$ & Brown ignimbrite \\
\hline \multicolumn{3}{|l|}{ Guapa } \\
\hline Unit A & Dark brown organic material. & Top soil \\
\hline Unit B & $\begin{array}{l}10 \text { to } 60 \mathrm{~cm} \text { thick pale brown carbon-rich clay, intersected to the north } \\
\left.\text { of the trench by gravel deposits associated to a paleochannel (Unit } B^{\prime}\right) \text {. }\end{array}$ & Pale brown paleosol \\
\hline Unit $C$ & $\begin{array}{l}40 \mathrm{~cm} \text { thick dark brown carbon-rich sandy clay formation with } \\
\text { abundant blocks of andesite and various ceramic remnants. }\end{array}$ & Dark brown paleosol \\
\hline Unit D & $\begin{array}{l}\text { Mafic, vesiculated and rounded andesite lava blocks, up to } 50 \mathrm{~cm} \text { in } \\
\text { diameter, in a mud (clay) matrix. }\end{array}$ & Colluvium deposit \\
\hline Unit $E$ & $\begin{array}{l}30-50 \mathrm{~cm} \text { thick brown-grey carbon-rich sandy and high volcanic ash } \\
\text { content formation. At Guapa 2, the bottom of Unit } \mathrm{E} \text { is a gravels } \\
\text { supported layer without sorting and with a brown clay matrix. }\end{array}$ & Ash rich paleosol \\
\hline Unit $F$ & $\begin{array}{l}\text { Up to } 60 \mathrm{~cm} \text { thick alternated reworked yellow ignimbrite material, with } \\
\text { pumice clasts }(<0.5 \mathrm{~cm}) \text { and matrix of glass shards, phenocrysts of } \\
\text { biotite (abundant), and hornblende. }\end{array}$ & Epiclastic volcanic deposits \\
\hline Unit $G$ & $\begin{array}{l}\text { Yellow massive volcanic ash formation with small pumice clasts }(<0.5 \\
\mathrm{cm}) \text { and glass-shards matrix, phenocrysts of quartz, plagioclase, } \\
\text { hornblende and oxidized biotite. }\end{array}$ & $\begin{array}{l}\text { Ignimbrite (possibly } \\
\text { reworked) }\end{array}$ \\
\hline Unit $H$ & Scoriae and andesite blocks. & Andesitic lava flow \\
\hline \multicolumn{3}{|c|}{ Hermoso } \\
\hline Unit A & 10 to $30 \mathrm{~cm}$ thick black silt and clay. & Top soil \\
\hline Unit B & 40 to $60 \mathrm{~cm}$ thick dark brown crystal rich clay. & $\begin{array}{l}\text { Dark clay (epiclastic } \\
\text { volcanic deposits) }\end{array}$ \\
\hline Unit $C$ & $\begin{array}{l}45 \mathrm{~cm} \text { thick brown muddy clay deposit with abundant volcanic ash and } \\
\text { clasts of different composition, rich in organic matter. }\end{array}$ & $\begin{array}{l}\text { Brown clay (epiclastic } \\
\text { volcanic deposits) }\end{array}$ \\
\hline Unit D & 10 to $20 \mathrm{~cm}$ thick matrix-supported deposit, clasts of rounded andesite. & Debris flow deposit \\
\hline Unit E & Ash-supported grey clay deposit with paleosol on top. & $\begin{array}{l}\text { Grey clay (epiclastic } \\
\text { volcanic deposits) }\end{array}$ \\
\hline Unit $F$ & $\begin{array}{l}10 \text { to } 40 \mathrm{~cm} \text { thick white angular clast-supported pumice deposit with } \\
\text { eroded top. }\end{array}$ & Fall deposits, pumice \\
\hline Unit $G$ & $25 \mathrm{~cm}$ thick grey coarse pumice lapilli deposit. & Fall deposits, lapilli \\
\hline Unit $H$ & $\begin{array}{l}50-90 \mathrm{~cm} \text { thick deposit of brown muddy clay, with abundant volcanic } \\
\text { clasts and a crystals rich matrix. }\end{array}$ & $\begin{array}{l}\text { Brown clay (epiclastic } \\
\text { volcanic deposits) }\end{array}$ \\
\hline Unit I & Up to $2 \mathrm{~m}$ thick black and red scoria blocks in a scoriaceous matrix. & Lava flow (Scoria blocks) \\
\hline
\end{tabular}


Table 3. Comparison of paleoseismological data calculated along the different faults of the Acambay Graben. SED: Single Event Displacement.

\begin{tabular}{|c|c|c|c|c|c|c|c|c|c|}
\hline Faults & $\begin{array}{c}\text { Length } \\
(\mathbf{k m})\end{array}$ & Events & $\begin{array}{c}\text { Recurrence } \\
\text { time } \\
(\mathbf{k y r})\end{array}$ & $\begin{array}{c}\text { Maximum } \\
\text { SED } \\
(\mathrm{cm})\end{array}$ & $\begin{array}{c}\text { Average } \\
\text { displacement } \\
(\mathrm{cm})\end{array}$ & $\begin{array}{l}\text { Slip-rate } \\
(\mathrm{mm} / \mathrm{yr})\end{array}$ & $\begin{array}{l}\text { Amount } \\
\text { of } \\
\text { trenches }\end{array}$ & $\begin{array}{l}\text { Maximum } \\
\text { Magnitude }\end{array}$ & References \\
\hline $\begin{array}{l}\text { Acambay- } \\
\text { Tixmadejé }\end{array}$ & 42 & 4 & 3.6 & $46-58$ & 35 & 0.17 & 4 & 6.9 & $\begin{array}{c}\text { Langridge et } \\
\text { al., } 2000\end{array}$ \\
\hline Pastores & $33-39$ & 3 & $10-15$ & 50 & 30 & 0.03 & 2 & $6.6-6.8$ & $\begin{array}{c}\text { Langridge et } \\
\text { al., } 2013\end{array}$ \\
\hline Pastores & 20.4 & 5 & $1.1-2.6$ & $>29-37$ & Not calculated & $0.23-0.37$ & 2 & 6.7 & $\begin{array}{c}\text { Ortuño et al., } \\
2015\end{array}$ \\
\hline San Mateo & 13 & 3 & 11.6 & $52-196$ & 85 & 0.085 & 1 & $6.4-6.7$ & $\begin{array}{c}\text { Sunye-Puchol } \\
\text { et al., } 2015\end{array}$ \\
\hline Venta de Bravo & 47 & 8 & $1.9-2.4$ & $>100$ & 45 & $0.22-0.24$ & 5 & 6.9 & This study \\
\hline Temascalcingo & 21 & 6 & Clustering & 72 & Not calculated & 0.17 & 2 & 6.7 & $\begin{array}{c}\text { Ortuño et al., } \\
2018 \\
\end{array}$ \\
\hline Tepuxtepec & 7 & 2 & $2.5-2.7$ & 100 & Not calculated & $0.24-0.26$ & 1 & 6.5 & $\begin{array}{c}\text { Ortuño et al., } \\
2018\end{array}$ \\
\hline
\end{tabular}

